\title{
IN THE FACE OF DANGER: A COMPARATIVE ANALYSIS OF THE USE OF EMERGENCY POWERS IN THE UNITED STATES AND THE UNITED KINGDOM IN THE $20^{\mathrm{TH}}$ CENTURY
}

\author{
Brian McGiverin*
}

\begin{abstract}
"History teaches that grave threats to liberty often come in times of urgency, when constitutional rights seem too extravagant to endure."

- Justice Thurgood Marshall ${ }^{1}$
\end{abstract}

"It may help to understand human affairs to be clear that most of the great triumphs and tragedies of history are caused, not by people being fundamentally good or fundamentally bad, but by people being fundamentally people."2

This Note is an examination of emergency powers, a term which refers to the expanded authority that a government may exercise during an emergency. It will briefly examine emergency powers in general, and will then move to a comparative analysis of the use of emergency powers by the United States and the United Kingdom over the course of the last century.

Section I speculates on the legitimacy of emergency powers and then on the advisable means through which a government may exercise those powers. Section II delves into a comparative analysis of emergency powers in the United States and the United Kingdom - first a legal/political analysis of the means through which emergency power can be exercised by the respective government, followed by an historical evaluation of how those powers have actually been utilized.

\section{EMERGENCY POWERS IN THEORY}

\section{A. Emergency Power}

It is important to begin this exercise by defining what an emergency power is. In brief, it is the partial or complete suspension of a state's normal legal system, ${ }^{3}$ involving the expansion of government power through the

* JD Candidate 2008 (expected), Indiana University School of Law - Indianapolis. B.S. Criminology 2005, Indiana State University.

1. Skinner v. Ry. Labor Executives Ass'n, 489 U.S. 602, 635 (1989) (Marshall, J., dissenting).

2. Nell Gaiman \& Terry Pratchett, Good Omens 18 (1996).

3. GIORgio Agamben, State of EXCEPTION 23 (Kevin Attell trans., University of Chicago Press 2005). Agamben refers to a state's normal legal system as its "juridical order." 
curtailment of individual liberties and/or the reassignment of authority between the branches of government. ${ }^{4}$ The latter manifests in such a way that the lines between the political branches begin to blur, generally giving the executive branch the kind of influence over legislation and adjudication normally reserved for the other branches. 5

A persuasive justification for the use of emergency power by a modern constitutional democracy can be found in the notion that such a state's political system is designed with an intricacy predicated on the calm waters of a normal environment, and that the likelihood of successfully maintaining a government of such intricacy during the turbulence of a genuine crisis is low. ${ }^{6}$ This argument could be interpreted as applying to the state a form of the justification of necessity, necessitas legem non habet, which generally holds that a person may legitimately transgress against a rule of the legal system during circumstances in which acceding to the letter of the law would violate the law's ultimate purpose of furthering "the common well-being of men." This logic of necessity - the recognition that in order to ensure that the law is enforced justly it must "promote the achievement of higher values at the expense of lesser values" and allow a technical breach of legal mandates so that "a more desirable result than adherence to the law" may occur - harkens at least as far back as Aristotle. ${ }^{8}$

This should not suggest that the state itself has an inherent right to exist; that would directly conflict with the averment that legitimate governing authority is derived only from the consent of the governed. ${ }^{9}$ Rather, governments exist to secure the rights of the individual. ${ }^{10}$ Indeed, Locke went so far as to argue that rebellion against the state was justified if it sought to invade the liberties it was created to protect, dramatically positing that a government which made such an invasion was composed of rebels who had placed themselves in a state of war against the people. 11 It stands to reason, however, that within this normative restriction, a government could still legitimately expand its power vis-à-vis the individual if such an expansion was

Id.

4. Michael Freeman, Freedom OR SecurItY 6 (2003).

5. See AgAMBEN, supra note 3, at 7.

6. See FreEman, supra note 4, at 6.

7. AGAMBEN, supra note 3, at 24-25. See BlaCK'S LAW DictionaRY (8th ed. 2004) ("justification, n. 2. A showing, in court, of a sufficient reason why a defendant did what the prosecution charges the defendant to answer for. - Under the Model Penal Code, the defendant must believe that the action was necessary to avoid a harm or evil and that the harm or evil to be avoided was greater than the harm that would have resulted if the crime had been committed. Model Penal Code § 3.02. -- Also termed justification defense; necessity defense.")

8. Laura J. Schulkind, Note, Applying the Necessity Defense to Civil Disobedience Cases, 64 N.Y.U. L. REV. 79, 83 (1989).

9. THE DECLARATION OF INDEPENDENCE (U.S. 1776), available at http://www.archives.gov/national-archives-experience/charters/declaration_transcript.html.

10. Id.

11. John LOCKE, Two TREATISES OF GOVERnMENT $\S 227$ (1689), available at http://www.constitution.org/j1/2ndtreat.htm. 
consented to by the governed.

One permutation of the necessity justification as applied to state action, in which the state's existence is buttressed by emergency powers so that it may continue to exist into the future to perform its legitimate functions, is sometimes called "reason of state." 12 A small state temporarily curtailing individual liberty during a war in which it seeks to avoid being swallowed by a larger neighbor illustrates this form of necessity. A second permutation of necessity can be found in the phrase salus populi suprema lex, "the welfare of the people shall be the supreme law," 13 suggesting that a state has the moral imperative to exceed the mandates of written law when doing so is the only means of acting in accordance with its underlying purpose of pursuing its citizens' common wellbeing. ${ }^{14}$ One example of this second justification would be commandeering private property, by means of improper procedure, for use as life-saving shelter during a natural disaster.

Unfortunately, accepting that emergency powers could be exercised legitimately in theory does little to clear the muddy waters involved in questions over the legitimacy of their use in practice, because ideas such as "lesser evil" and "common good" are necessarily subjective determinations. ${ }^{15}$ Moral legitimacy is unavoidably jeopardized when it can conceivably be claimed with equal strength by both sides of a dispute. ${ }^{16}$ The subjectivity inherent in the normative evaluation of the underlying justifications for the use of the extraordinary powers adopted by states in times of emergency imbues their availability with a peril. Within the legalism of the modern state, governments have repeatedly used emergency powers as a means for "the physical elimination not only of political adversaries but of entire categories of citizens who for some reason [could not] be integrated into the political system."17

The legitimacy of emergency powers is further imperiled because the exigencies of the circumstances may well place a government in the position of acting as its own judge. The words of Abraham Lincoln effectively illustrate this point:

Every man thinks he has a right to live and every government thinks it has a right to live. Every man when driven to the wall by a murderous assailant will override all laws to protect himself, and this is called the great right of self-defense. So every government when driven to the wall by a rebellion will trample down a constitution before it will allow itself to be

12. Laura K. Donohue, Counter-Terrorist Law and EMERgenCy PoWers IN THE UNITED KINGDOM 1922-2000 331 (2001).

13. David Bonner, Emergency Powers in Peacetime 55 (J. P. W. B. McAuslan ed., 1985).

14. LOCKE, supra note $11, \S 160$.

15. AGAMBEN, supra note 3 , at 30 .

16. DonoHUE, supra note 12 , at 338.

17. AGAMBEN, supra note 3 , at 2. 
destroyed. This may not be constitutional law but it is a fact. ${ }^{18}$

Such a situation calls into question the legitimacy of the use of emergency powers, as being the judge of one's own case is a violation of the most basic principles of due process. ${ }^{19}$ As was stated by Madison, "[n]o man is allowed to be a judge in his own cause, because his interest would certainly bias his judgment, and, not improbably, corrupt his integrity."20

\section{B. Separation of Powers}

This analysis of emergency powers leaves us with something of a quandary. We find ourselves in a position in which statesmen will act on the basis of subjective notions of justice, which may or may not be shared by the citizenry through which governing authority derives legitimacy. Though clearly a tool of great power with the potential to be used for benevolent purposes, these powers cut both ways, in that they can and have been used for stunning malevolence. Do emergency powers amount to a sword with no handle, a tool which will inevitably expose us to the perils of an unbridled and capricious state? Perhaps not.

From the records available, it is evident that concern about the potential for a state to accumulate absolute power was planted firmly in the minds of the Founding Fathers. In the Federalist Papers, Madison pointed out with profound clarity that "[i]n framing a government which is to be administered by men over men, the great difficulty lies in this: you must first enable the government to control the governed; and in the next place oblige it to control itself." 21 The solution to this dilemma presented by the "Father of the Constitution" was a government of separated powers, in which each branch would serve as a check upon the others. ${ }^{22}$ Though all actors in government might be filled with ambition, dividing those people into groups with conflicting interests would help serve as an incentive for one branch to limit the institutional power of the other branches. "Ambition must be made to counteract ambition."24

Arguably, the availability of emergency powers undermines the possibility of a government of divided power, because the branch capable of triggering those powers can easily circumvent any bulwarks to its authority. ${ }^{25}$ In other words, a President capable of ignoring Congress and the Judiciary may

18. BONNER, supra note 13 , at 2 .

19. JohN V. ORTH, DUE PROCESS OF LAW 15-32 (2003).

20. THE FEDERALIST No. 10 (James Madison), available at http://thomas.loc.gov/home/histdox/fed_10.html [hereinafter FEDERALIST No. 10].

21. THE FEDERALIST No. 51 (James Madison), available at http://thomas.loc.gov/home/histdox/fed_51.html [hereinafter FEDERALIST No. 51].

22. Id.

23. $I d$.

24. Id.

25. FreEMAN, supra note 4, at 42. 
as well be called king. This is not necessarily so, however, because although the activation of emergency powers moves a state to a juridical order different than that used during normal circumstances, it is possible for the principles of self-restrained government to continue serving as a bridle for state power. 26 What is required is a division between the authority to trigger emergency power and the authority to exercise emergency power.27 Justice Souter opined:

In a government of separated powers, deciding finally on what is a reasonable degree of guaranteed liberty whether in peace or war (or some condition in between) is not well entrusted to the Executive Branch of Government, whose particular responsibility is to maintain security. For reasons of inescapable human nature, the branch of the Government asked to counter a serious threat is not the branch on which to rest the Nation's entire reliance in striking the balance between the will to win and the cost in liberty on the way to victory... A reasonable balance is more likely to be reached on the judgment of a different branch, just as Madison said in remarking that "the constant aim is to divide and arrange the several offices in such a manner as that each may be a check on the other-that the private interest of every individual may be a sentinel over the public rights." ${ }^{28}$

If designed thusly, not only does the initial activation of emergency power require the consent of competing branches of government, it also provides both the opportunity to continuously monitor the use of those powers and the key to their revocation. ${ }^{29}$

\section{Influence of the Citizenry}

Despite lengthy reflections on mitigating the chances of tyranny by dividing the government into separate branches, it seems that the Founding Fathers did not consider that sort of internal restraint to be the first bulwark against the abuse of power.30 Rather, as Madison wrote, "[a] dependence on the people is, no doubt, the primary control on the government." ${ }^{\text {"31 }}$ In justifying the creation of a new federal government with more power than that which was afforded under the Articles of Confederation, Madison argued that a large republic would be less likely to devolve into an authoritarian state than a small republic because, by increasing the size of a republic, one also increases the

26. See id.

27. Id.

28. Hamdi v. Rumsfeld, 542 U.S. 507, 545 (2004) (Souter, J., concurring).

29. See FreEMAN, supra note 4, at 43.

30. See The Federalist No. 51, supra note 21 .

31. Id. 
number of citizens, and in doing so "you take in a greater variety of parties and interests; you make it less probable that a majority of the whole will have a common motive to invade the rights of other citizens." 32 Thus, a diverse array of distinct interests ameliorates the chances of finding a political faction which includes a majority of the state's citizens, which might be willing to invade the rights of the remainder, "sacrific[ing] to its ruling passion or interest both the public good and the rights of other citizens." 33

Despite the apparent strength of Madison's reasoning, the United States has experienced many periods in which the political demands of the day have led to the new and immediate invasion of a minority group's rights. Some commentators have suggested that events such as the Sedition Act of 1798, the prosecution of northern antiwar advocates during the Civil War, the Espionage and Sedition Acts of World War I, Japanese internment during World War II, and the Smith and Internal Security Acts of the McCarthy era are representative of "a form of constitutional pathology, during which the nation's foundational commitment to civil liberties is either seriously undermined or all but abandoned."34 This phenomenon can be explained within Madison's framework by utilizing contemporary observations of social mechanics. The relationship between citizen and government in general is much more complex than Madison's description. While it seems to be true that government policy is dependant upon public opinion, ${ }^{35}$ public opinion itself tends to be highly malleable; social mechanisms sometimes allow the "cognitive errors, emotive responses, and moral stratagems" of a few people to be amplified and transferred to a much larger group. ${ }^{36}$ Public opinion may be influenced by a "social cascade" in which "many people end up thinking something," either factual or normative, "because of the beliefs or actions of a few early movers."37 This can be observed in the reaction caused by the opinions of so-called elites (e.g. "politicians, journalists, policy experts, certain activists" and others who are the most vocal about contemporary political issues), which can influence the public to the point of inducing "citizens to hold opinions that they would not hold if aware of the best available information and analysis."38

Alternatively, popular opinion can be affected through group polarization, in which "[g]roup cohesiveness, self-censorship, insulation, and homogeneous

32. The Federalist No. 10, supra note 20.

33. Id.

34. Martin H. Redish, The Logic of Persecution 46-49 (2005).

35. Nancy C. Wilkie, Public Opinion Regarding Cultural Property Policy, 19 CARDOZO ARTS \& ENT. L.J. 97, 99-100 (2001).

36. Jonathan H. Marks, $9 / 11+3 / 11+7 / 7=$ ? What Counts in Counterterrorism, 37 Colum. Hum. RTS. L. REv. 559, 574 (2006).

37. Id. at 574-76.

38. Doni Gewirtzman, Glory Days: Popular Constitutionalism, Nostalgia, and the True Nature of Constitutional Culture, 93 GEO. L.J. 897, 928-30 (2005). See also Michael K. Gusmano, Policy Feedback and Public Opinion: The Role of Employer Responsibility in Social Policy, 27 J. HEALTH POL. POL'Y \& L. 731, 735 (2002). 
ideology" cause a person to adopt the opinion of a group with whom he identifies, through a process of "selective bias in the processing of information, failure to survey and assess alternatives adequately, or reluctance to examine the risks of a preferred choice." ${ }^{, 39}$ These patterns of human interaction might explain why there tends to be a temporary surge of public opinion in support of government policy during times of emergency, sometimes called the "rallyround-the flag" effect, ${ }^{40}$ which may in turn create a condition appropriately described in Madisonian terms as a temporary majority faction - i.e. the alignment of otherwise politically heterogeneous groups temporarily united by fear and a concern for national security. Finally, in the long term, simple inertia may influence public opinion, in that individuals become accustomed to and accepting of a government policy after being subjected to it over time. ${ }^{41}$

This ability of society to surmount procedural guards against tyranny is especially alarming when one considers that in a time of emergency the majority may choose to demonize a specific minority group, categorizing it as an antagonist within a normative framework which serves the natural human desire "to impose order on events that are experienced as irrational and frightening." ${ }^{, 42}$ As Carl Jung averred,

The real existence of an enemy upon whom one can foist off everything evil is an enormous relief to one's conscience. You can then at least say, without hesitation, who the devil is; you are quite certain that the cause of your misfortune is outside, and not in your own attitude. ${ }^{43}$

Many theories have been put forward in an attempt to explain this phenomenon. One, a theory of delinquency developed by Sykes and Matza, allows for the selective neutralization of particular norms that are characteristic of the dominant social order. "The perpetrator claims an exceptional situation in which breaking the norm is justifiable without questioning the validity of the norm as such. Neutralization thus makes it possible for the violation to appear acceptable, if not legitimate." A second theory posits that individuals are capable of using moral compartmentalization to establish an alternative moral

39. Marks, supra note 36 , at 576-77.

40. Jide Nzelibe, A Positive Theory of the War-Powers Constitution, 91 Iowa L. REv. 993,1005 n. 26 (2006).

41. Gusmano, supra note 38 , at $734-35$.

42. Collin O'Connor Udell, Parading the Saurian Tail, 42 Ariz. L. Rev. 731, 749-50 (2000).

43. Id. at 752 .

44. Frank Neubacher, How Can it Happen That Horrendous State Crimes Are Perpetrated?, 4 J. INT'L CRIM. JUST. 787, 792-794 (2006). The five individual techniques are denial of responsibility, denial of injury, denial of the victim, condemnation of the condemners, and appeal to higher loyalties. Id.

45. Id. at 792. 
framework to apply to an exceptional circumstance while avoiding feelings of moral dissonance, even though it conflicts with the old moral framework that the person otherwise continues to hold. ${ }^{46}$ A third theory holds that an individual may dehumanize a person, relegating him from what he regards as the "in-group" to the "out-group", effectively moving him outside of the community to whom he feels morally bound. ${ }^{47}$ In any of these situations, the protection normally provided by political pluralism would arguably fall away, leaving the rule of law as the only protection for the rights of the targeted minority.

\section{COMPARATIVE ANALYSIS}

\section{A. The United States}

\section{The American System of Emergency Power}

As previously discussed, evocating emergency powers may involve either a transfer of authority between the branches of government (generally to the effect of strengthening the executive branch) or the expansion of government authority at the expense of individual liberties. ${ }^{48}$ While the United States has had occasion to use the latter method, it has in large part managed to abstain from altering the formal balance of power between the three branches as a means of dealing with emergencies, especially when compared to the United Kingdom. ${ }^{49}$

Aside from the limited powers exclusively afforded to the executive branch by Article II of the Constitution, the President's legitimate domain of action is defined by Congressional mandate ${ }^{50}$ and has traditionally been evaluated within that context. ${ }^{51}$ As such, the courts have been protective of the

46. Marks, supra note 36 , at 571-72, 579-82.

47. Neubacher, supra note 44 , at 792.

48. Supra section I(A).

49. Infra section II(B).

50. Youngstown Sheet \& Tube Co. v. Sawyer, 343 U.S. 579, 637-38 (1952) (Jackson, J., concurring). The formula for Presidential power described in Justice Jackson's concurrence has been the most influential articulation from Youngstown. Jason Collins Weida, Note, A Republic of Emergencies, 36 CONN. L. REv. 1397, 1430-1433 (2004). Or, at least, within as much of a mandate as one can hope for within the context of the ambiguity characteristic of the legislature. See Daryl J. Levinson \& Richard H. Pildes, Separation of Parties, Not Powers, 119 HARV. L. REV. 2311, 2353-54 (2006).

51. Compare Ex parte Mitsuye Endo, 323 U.S. 283 (1944) (finding that although the power to detain citizens of Japanese descent was a legitimate activity of the executive because it was impliedly authorized by Congress as a necessary step to achieving an explicitly authorized goal - the removal of said persons from designated military areas -, the detention of a concededly loyal citizen of Japanese descent was not legitimate, as Congress's purpose in authorizing exclusion was to prevent the occurrence espionage and sabotage by those who were 
right to due process as a means of ascertaining whether the executive is acting within the realm its legitimate authority, ${ }^{52}$ finding that individuals have the right to a minimum degree of due process regardless of the difficulty that it presents the government. ${ }^{53}$ The courts have simultaneously ruled, however, that due process can be satisfied through the use of military tribunals ${ }^{54}$ - non-Article III courts which may be convened under the authority of the jointly-held war powers of the President and Congress to try individuals for violations of the laws of war. ${ }^{55}$ These tribunals can only exercise jurisdiction over an American citizen if he is in military service, if he is tried at a time when Article III courts are not functioning, or if he is accused of being an unlawful combatant. ${ }^{56}$

Congress, in defining the powers of the executive in times of emergency, faces few obstacles. Though the Supreme Court has made grandiose claims during times of peace that no emergency could justify Congressional transgression upon certain inalienable rights, ${ }^{57}$ an observation of judicial history reveals that in times of emergency the Supreme Court will acquiesce to restrictions of individual rights that it would not allow during times of normalcy. ${ }^{58}$ Rather than enforcing civil rights against the government, the Court has preferred to endorse the liberty/security balances sought by Congress. 59 "Thus, although there are no specific emergency powers as such, the interpretation of the Supreme Court of the United States has been flexible enough to permit required action to be taken to meet emergencies." Speculation over the Court's motivation for doing so include the presumption

potentially disloyal) and Sarah A. Whalin, Note, National Security Versus Due Process: Korematsu Raises its Ugly Head Sixty Years Later in Hamdi and Padilla, 22 GA. ST. U. L. REV. $711,716-17$ (2006) with Hamdi v. Rumsfeld, 542 U.S. 507, 518-19 (2004) (finding that detention, when used "to prevent a combatant's return to the battlefield" is "a fundamental incident of waging war," and was thus impliedly authorized by Congress in the "necessary and appropriate force" language of Congress's Authorization for Use of Military Force) and Whalin, supra note 53 , at $722-23$.

52. See Hamdi, 542 U.S. at 528-36 (finding the government's obligation to provide an individual with due process wanes in the face of national security concerns, but that the "essential constitutional promises" of receiving "notice of the factual basis for his classification, and a fair opportunity to rebut the Government's factual assertions before a neutral decisionmaker" cannot be abridged). See also Whalin, supra note 51, at 724-26.

53. Hamdi, 542 U.S. at 538.

54. Id. ("There remains the possibility that the standards we have articulated could be met by an appropriately authorized and properly constituted military tribunal").

55. Benjamin V. Madison, III, Trial by Jury or by Military Tribunal for Accused Terrorist Detainees Facing the Death Penalty? An Examination of Principles that Transcend the U.S. Constitution, 17 U. FLA. J.L. \& PUB. POL'Y 347, 366-90 (2006).

56. Id.

57. See John S. Richbourg, Liberty and Security: The Yin and Yang of Immigration Law, 33 U. MEM. L. REV. 475, 488-90 (2003). See also Avigael N. Cymrot, Reading, Writing, and Radicalism: the Limits on Government Control Over Private Schooling in an Age of Terrorism, 37 ST. MARY's L.J. 607, 635-36 (2006).

58. W.S. Tarnopolsky, Emergency Powers and Civil Liberties, Canadian PUBLIC Administration, Vol. 15 Issue 2, 1972, at 201.

59. Levinson, supra note 50 , at 2350.

60. Tarnopolsky, supra note 58, at 202-03. 
that the Court acknowledges that balancing liberty against security requires an ability to gather information for which the courts are comparatively ill equipped ${ }^{61}$ that the Court is concerned that decisions made contrary to the wishes of Congress and the President would not be enforced; ${ }^{62}$ and the possibility that the Justices, as individuals, shared the belief-structures which galvanized the rest of society during times of perceived emergency. ${ }^{63}$

The greatest opposition that the Court has shown to the other branches of government has probably been in the preservation of its own role in the tripartite system. The judiciary as a whole faces the real possibility of being nudged into a lesser position depending on the interpretation given to the Constitution's Suspension Clause, ${ }^{64}$ which governs the suspension of the writ of habeas corpus and thus judicial review of detention by the government; and the Exceptions Clause, ${ }^{65}$ which governs Congress's control of the Supreme Court's appellate jurisdiction. In the past, the Court has preferred to interpret both clauses on statutory rather than Constitutional grounds. ${ }^{66}$ Consequently, the precise meaning of each clause is still the source of intense debate among jurists. Both sides of the debate over the Suspension Clause appear to agree

61. David Cole, Judging the Next Emergency: Judicial Review and Individual Rights in Times of Crisis, 101 MiCH. L. REv. 2565, 2570 (2003).

62. Id. at 2570-71.

63. Id. at 2570. See also REDISH, supra note 35 , at 57.

64. U.S. ConST. art. I, $\S 9$, cl. 2.

65. U.S. CoNST. art. III, $\S 2$, cl. 2

66. E.g. Felker v. Turpin, 518 U.S. 651, 660-62 (1996).

No provision of Title I mentions our authority to entertain original habeas petitions; in contrast, $\S 103$ amends the Federal Rules of Appellate Procedure to bar consideration of original habeas petitions in the courts of appeals. Although $\S 2244(\mathrm{~b})(3)$ (E) precludes us from reviewing, by appeal or petition for certiorari, a judgment on an application for leave to file a second habeas petition in district court, it makes no mention of our authority to hear habeas petitions filed as original matters in this Court. As we declined to find a repeal of $\S 14$ of the Judiciary Act of 1789 as applied to this Court by implication then, we decline to find a similar repeal of $\$ 2241$ of Title 28 -its descendant, $n$. 1, supra-by implication now. This conclusion obviates one of the constitutional challenges raised. .. The Act does remove our authority to entertain an appeal or a petition for a writ of certiorari to review a decision of a court of appeals exercising its "gatekeeping" function over a second petition. But since it does not repeal our authority to entertain a petition for habeas corpus, there can be no plausible argument that the Act has deprived this Court of appellate jurisdiction in violation of Article III, \& 2.

Id., See also I.N.S. v. St. Cyr, 533 U.S. 289, 301 n. 13 (2001) (finding " [t] $]$ he fact that this Court would be required to answer the difficult question of what the Suspension Clause protects is in and of itself a reason to avoid answering the constitutional questions that would be raised by concluding that review was barred entirely"); Hamdan v. Rumsfeld, 464 F. Supp.2d 9, 15 (D.C. 2006) ("In two relatively recent cases involving the Antiterrorism and Effective Death Penalty Act of 1996 (AEDPA) and the Illegal Immigration Reform and Immigrant Responsibility Act of 1996 (IIRIRA), indeed, the Court has carefully avoided saying exactly what the Suspension Clause protects"). 
that it requires some degree of judicial review over an individual's detention. ${ }^{67}$ The real bone of contention is whether it protects the judiciary's ability to utilize the writ as a cause of action, ${ }^{68}$ or if the clause would allow for the abridgement of the writ if alternative avenues for judicial review of detainment were instituted. ${ }^{69}$ A similar debate rages over the Exceptions Clause. At one extreme is the belief that Congress's authority to limit the Court's appellate jurisdiction is absolute; at the other extreme is the notion that the nation's whole judicial power is vested somewhere in the federal judiciary. ${ }^{70}$ Intermediate ideas generally involve the notion that the whole power of the federal judiciary must be vested somewhere, though not necessarily with the Supreme Court. $^{71}$

The meaning of the Suspension Clause, at least, may soon be made clearer as a result of the recently passed Military Commissions Act of 2006 ("MCA"). ${ }^{72}$ Section 7 of the MCA inserted new language into 28 U.S.C.A. $§$ 2241 , the statute defining the federal courts' ability to issue of a writ of habeas corpus, providing the following:

No court, justice, or judge shall have jurisdiction to hear or consider an application for a writ of habeas corpus filed by or on behalf of an alien detained by the United States who has been determined by the United States to have been properly detained as an enemy combatant or is awaiting such determination. $^{73}$

This language has the potential to abridge the Suspension Clause in only a particular set of circumstances. The first is through petitions by detainees held at Guantanamo Bay, Cuba. The Court ruled quite some time ago that noncitizens receive the protections of the individual rights embodied in Constitution only when they are within the "territory over which the United States is sovereign,"74 though there has been some indication since then that the Court might ultimately move away from a strictly territorial approach to the Constitution, ${ }^{75}$ or that it might question whether the writ of habeas corpus

67. Janet Cooper Alexander, Jurisdiction-Stripping in the War on Terrorism, 2 STAN. J. Civ. RTS. \& Civ. LiBERTIES 259, 285 (2006).

68. Id. at 277. See also Gerald L. Neuman, Habeas Corpus, Executive Detention, and the Removal of Aliens, 98 CoLUM. L. Rev. 961, 969 (1998).

69. Alexander, supra note 67, at 285. See also Richard H. Fallon, Jr., Response, Applying the Suspension Clause to Immigration Cases, 98 CoLUM. L. REv. 1068, 1082-84 (1998).

70. Richard E. Levy \& Sidney A. Shapiro, Government Benefits and the Rule of Law: Toward a Standards-Based Theory of Judicial Review, 58 ADMIN. L. REv. 499, 529-30 (2006).

71. Id. at 530-32.

72. Military Commissions Act of 2006, Pub. L. No. 109-366, 120 Stat. 2600 (2006).

73. Power to grant writ, 28 U.S.C.A. § 2241 (e)(1).

74. Johnson v. Eisentrager, 339 U.S. 763, 777-78 (1950). See also Kal Raustiala, The Geography of Justice, 73 FORDHAM L. REV. 2501 , 2532 (2005).

75. See Reid v. Covert, 354 U.S. 1 (1957) (ruling Americans abroad would be protected 
should even be considered an individual right, or rather if the writ is a restriction on Congress's ability to legislate, which would be applicable in all circumstances. ${ }^{76}$ At this moment, the United States government contends that sovereignty over Guantanamo Bay remains with $\mathrm{Cuba}^{77}$ as was stated in the lease agreement made when control over the territory was acquired, ${ }^{78}$ and so far the courts have been receptive to that claim.79 The second instance in which the MCA has the potential to abridge the Suspension Clause is in regard to aliens within the territorial United States who may be detained. ${ }^{80}$ In instances of detainment followed by prosecution, the Suspension Clause may be satisfied if the Supreme Court sides with the interpretation of the clause which merely requires judicial review; ${ }^{81}$ however, the procedures outlined in the MCA would not, by any stretch of the imagination, satisfy the Suspension Clause for noncitizens who are detained within this country without being brought to trial. $^{82}$

\section{World War I and the Red Scare}

At the time of America's entry into the World War I, and the time immediately preceding it, there was little popular support for intervening in the conflict; in fact several politicians were elected into office on antiwar campaign platforms. ${ }^{83}$ This environment of apathy and dissent among the populace led the Wilson administration to attempt the cultivation of war-time hysteria, ${ }^{84}$ and

by rights granted under the Constitution for the first time). See also Elizabeth A. Wilson, The War on Terrorism and "The Water's Edge": Sovereignty, "Territorial Jurisdiction," and the Reach of the US Constitution in the Guantanamo Detainee Litigation, 8 U. PA. J.CONST. L. 165, 192-93 (2006).

The last concentric circle is a dotted one, because it represents a doctrinal development that was not formally adopted by the Supreme Court. After Reid v. Covert, the Supreme Court decided several other cases involving citizens under military jurisdiction, but the Court did not tum its attention to aliens abroad again until 1990 in Verdugo-Urquidez. In the intervening years, lower courts took guidance from Reid and looked to the concept of control, rather than sovereignty, as the trigger of constitutional rights. In this phase of expansion in the extraterritorial application of the Constitution, the Constitution was extended to territories over which the United States was not technically sovereign, but Id. at 193. exercised significant control and authority.

76. Boumediene v. Bush, 476 F.3d 981, 994-95 (D.C. Cir. 2007) (Rogers, dissenting), cert. granted, 127 S.Ct. 3078 (Jun 29, 2007). The Supreme Court will weigh in on this important case sometime in its 2007-2008 term.

77. Raustiala, supra note 74 , at 2501 .

78. Rasul v. Bush, 542 U.S. 466, 471 (2004).

79. Boumediene, 476 F.3d at $991-92$.

80. Military Commissions Act, Pub. L. No. 109-366, 120 Stat. $2600 \S 950 \mathrm{~g}(2006)$.

81. Alexander, supra note 67 , at 286-87.

82. Id. at $287-90$.

83. Howard Zinn, Forward to StePhen M. Kohn, AMERICAN PoltTiCal Prisoners xii (1994).

84. REDISH, supra note 34 , at 50. 
the means through which it did so was the creation of a propaganda agency known as the Committee on Public Information (CPI) ${ }^{85}$ This agency, created less than a week after the declaration of war, ${ }^{86}$ "flooded the public with pamphlets, press releases, newsreels, and even government-authored political cartoons," by some accounts leading newspapers to publish "at least 20,000 columns of CPI material each week." for the war were ultimately very successful. ${ }^{88}$

Two months after America entered the war, Congress passed the Espionage Act of $1917,{ }^{89}$ which criminalized espionage and sought to punish those who willfully caused, attempted to cause, or conspired to cause interference with the draft, or "insubordination, disloyalty, mutiny, or refusal of duty" in the armed forces, with a fine of $\$ 10,000$ or up to twenty years in prison. ${ }^{90}$ The following year, the Espionage Act was amended by the Sedition Act of $1918,{ }^{91}$ making the list of acts which incurred the above punishment even more extensive, significantly limiting freedom of speech as it related to the war. A portion of the expanded list of proscribed activities read:

whoever, when the United States is at war, shall willfully utter, print, write, or publish any disloyal, profane, scurrilous, or abusive language about the form of government of the United States, or the Constitution of the United States, or the military or naval forces of the United States, or the flag of the United States, or the uniform of the Army or Navy of the United States, or any language intended to bring the form of government of the United States, or the Constitution of the United States, or the military or naval forces of the United

85. Robert Justin Goldstein, POLITICAL RePression In MODERN AMERICA 105 (1978). See also Ann Bartow, Trademarks of Privilege: Naming Rights and the Physical Public Domain, 40 U.C. DAVIS L. REV. 919, 957 n. 117 (2007).

Wilson hired a publicist, George Creel, to head the "Committee on Public Information" (CPI)--a propaganda ministry with the sole purpose of "selling the war." CPI produced films, pamphlets, curriculum guides--all designed to "paint Germany in a bad light." Wilson's propaganda ministry encouraged businesses to spy on their employees, parents to spy on their children, and neighbors to spy on neighbors. Most importantly, the CPI urged Americans to report "disloyal" proGerman sentiments. Creel himself stated that he demanded, "100\% Americanism."

Id.

86. The United States declared war on Germany on April 6,1917. The CPI was created by executive order on April 13. J. Gregory Sidak, The Price of Experience: The Constitution After September 11, 2001, 19 CONST. COMMENT. 37, 54 n. 58 (2002).

87. Jodie Morse, Note, Managing the News: The History and Constitutionality of the Government Spin Machine, 81 N.Y.U. L. REV. 843, 850 (2006).

88. GOLDSTEIN, supra note 85 , at 105.

89. Espionage Act of 1917 , ch. $30, \S 1,40$ Stat. 217 (1917).

90. Espionage Act of 1917, 40 Stat. $217 \S \S 3-4$. See also KoHN, supra note 83, at 8.

91. Sedition Act of 1918, ch. 75, § 1, 40 Stat. 553 (1918) (repealed 1921). 
States, or the flag of the United States, or the uniform of the Army or Navy of the United States into contempt, scorn, contumely, or disrepute . . . and whoever shall by word or act support or favor the cause of any country with which the United States is at war or by word or act oppose the cause of the United States therein, shall be punished by a fine of not more than $\$ 10,000$ or imprisonment for not more than twenty years, or both .... 92

In the case of each law, both Representatives and Senators unabashedly admitted that their motivation for supporting the legislation was derived from the desire to suppress domestic dissent ranging from anti-war passivism, to union activism, to racial tensions. ${ }^{93}$

The combination of the feverish public opinion fostered by the CPI and the laws passed by Congress to limit the ability of private individuals to express opposition to the war defined a period arguably characterized by the "the virtual complete collapse of support for concepts of civil liberties among all segments of the population except for those groups that came under direct attack."94 It was within this vacuum that the government presided over the dismembering of two groups which had formed a core of political dissent in the nation for decades: the International Workers of the World (IWW) and the Socialist Party of America (SPA).

The IWW was one of the most successful American unions in the late nineteenth and early twentieth centuries, a time when unionization was not legal and strikes were sometimes ended violently by private strike breakers and/or the government. ${ }^{95}$ By 1917, the group had expanded to about 100,000 members. ${ }^{96}$ Conversely, the SPA had achieved a great deal of success in the political realm, with Socialists being elected to Congress and over a thousand municipal offices across the country, ${ }^{97}$ due in part to their antiwar election

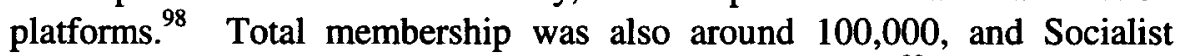
literature was routinely sent to roughly one million people. ${ }^{99}$ The Espionage and Sedition Acts were "used to systematically destroy" both organizations. ${ }^{100}$

Many of the top leaders of the SPA were arrested immediately before the off-year elections in November 1917, disrupting the party's political activity and sometimes culminating in the jailing of candidates. ${ }^{101}$ After the election,

92. Sedition Act of $1918 \S 3$ (emphasis added).

93. KoHN, supra note 83, at 8-9.

94. REDISH, supra note 34 , at 50.

95. GOLDSTEIN, supra note 85 , at $90-94$.

96. Id. at 98 .

97. Howard Zinn, Forward to KoHN, supra note 83, at xii.

98. Id.

99. Id.

100. Id. at 14.

101. GOLDSTEIN, supra note 85, at 119. 
"sedition indictments were returned against virtually every major SPA leader," some of whom received twenty year sentences. ${ }^{102}$ Eugene Debs, who had been the SPA's presidential candidate five-times, was also arrested and convicted. ${ }^{103}$ Further, by the end of the war, virtually all of the leaders of the IWW had been arrested, as well. ${ }^{104}$ Put into mass trials, they were prosecuted under the theory that the IWW had distributed statements and made speeches against the war and/or the United States. ${ }^{105}$ Hundreds were convicted, mostly on charges of conspiracy, with their IWW membership being the only evidence against them. ${ }^{106}$ Ultimately, about 2100 people were indicted under the acts, and about 1000 convicted, ${ }^{107}$ none of whom were convicted for the sections of the act genuinely related to espionage. ${ }^{108}$

Three convictions based upon this abridgment of freedom of speech reached the Supreme Court. ${ }^{109}$ In the first, Schenck v. United States, ${ }^{110}$ Justice Holmes articulated the "clear and present danger" test for the first time, which on its face appeared to be a substantially more protective doctrine than that previously used by the Court. ${ }^{111}$ However, while he argued in favor of this new doctrine in dissenting opinions in subsequent years, ${ }^{12}$ in the unanimous opinion that he authored in Schenck, Holmes upheld a conviction for printing anti-war circulars, ${ }^{113}$ and in doing so he appears to have failed to apply his newly articulated test in place than the older "bad tendency" test, given that he declined to offer any evidence that the leaflets amounted to a "clear and present danger." 114 Rather, in explaining the Court's balancing of the national interest against the First Amendment, Holmes stated:

[w]e admit that in many places and in ordinary times the defendants in saying all that was said in the circular would have been within their constitutional rights. But the character of every act depends upon the circumstances in which it is done... When a nation is at war many things that might be said in time of peace are such a hindrance to its effort that their utterance will not be endured so long as men fight and that no Court could regard them as protected by any

102. Id.

103. Id.

104. Id. at 118.

105. KoHN, supra note 83 , at 14.

106. GoLDSTEIN, supra note 85 , at $117-118$.

107. Id. at 113 .

108. Id.

109. Robert S. Tanenbaum, Preaching Terror, 55 AM. U. L. REV. 785, 793 (2006).

110. Schenck v. United States, 249 U.S. 47, 52 (1919).

111. David G. Bamum, The Clear and Present Danger Test in Anglo-America and European Law, 7 SAN DIEGO INT'L L.J. 263, 272 (2006).

112. Id. at 275-76.

113. Tanenbaum, supra note 109 , at 794 .

114. Barnum, supra note 111 , at 272 . 
constitutional right. ${ }^{115}$

Holmes failed to even mention the clear and present danger test ${ }^{116}$ in the opinions he authored for Frohwerk v. United States ${ }^{117}$ and Debs v. United States $^{118}$ just one week later.

The period in the United States immediately after the First World War has come to be known as the Red Scare. ${ }^{119}$ Several intervening events had occurred between America's entry into the war and the end of 1919 which served to inflame public opinion. In particular, in November of 1917, the Bolsheviks seized control of Russia and, following the armistice with Germany in 1918, several communist uprisings occurred in the territory of the defeated Central Powers. ${ }^{120}$ At roughly the same time that these foreign events were seeding domestic fears, many communist parties were forming in the United States. ${ }^{121}$ The fact that these new parties were heavily composed of aliens, who Americans had traditionally associated with radicalism, helped to create a demand among the citizenry to deport aliens that were involved in radical political activities. ${ }^{122}$ Subsequently, on January 2, 1920, federal agents, under the direction of Attorney-General Alexander Palmer, swept down on 30 cities, arresting between five and ten thousand people, two to seven thousand of whom were arrested without warrants. ${ }^{123}$ This raid, along with one the previous December, came to be known as the Palmer Raids. ${ }^{124}$ At the time, Congress, the press, and the public clamored for mass deportation of those arrested, ${ }^{125}$ and the courts decided that deportation hearings were an administrative matter not subject to the courts' review. ${ }^{126}$ The fate of those detained appeared to be set.

Ultimately, the executive branch's hand was temporarily stayed by the administrators of the Department of Labor, which at the time was responsible for approving deportations, who balked at deporting the detainees en mass. ${ }^{127}$ Before this obstruction could be circumvented, the public hysteria began to subside and many respected Americans began to speak out against the raids and the invasions of civil liberties that had been committed. ${ }^{128}$ In May, a group of prominent lawyers released an extensive report condemning the illegality of the

115. Schenck, 249 U.S. at 52.

116. Barnum, supra note 111 , at 273 . Tanenbaum, supra note 109 , at $794-95$.

117. Frohwerk v. United States, 249 U.S. 204 (1919).

118. Debs v. United States, 249 U.S. 211 (1919).

119. REDISH, supra note 34 , at 50.

120. William M. Wiecek, The Legal Foundations of Domestic Anticommunism, 2001 SuP. CT. REV. 375, 387 (2001).

121. GoLDSTEIN, supra note 85 , at $153-54$.

122. Id.

123. Id. at 156 .

124. REDISH, supra note 34 , at 50.

125. EDWIN P. HOYT, THE PALMER RAIDS 1919-1920 107 (1969).

126. GOLDSTEN, supra note 85 , at 154.

127. Id. at 160 .

128. REDISH, supra note 34 , at 51 . 
raids, ${ }^{129}$ and similar opposition arose from the press, religious figures, and lower branches of the judiciary. ${ }^{130}$ Soon thereafter, the Department of Labor began to make individual rulings over deportation cases and found that no basis for deportation existed in the majority of cases. ${ }^{131}$ In the end, only 556 of the people originally detained (about 5-10 percent) were deported. ${ }^{132}$ When, in response, the President demanded that Congress begin impeachment proceedings against the Assistant Secretary of Labor who was responsible for these unanticipated events, the House Rules Committee concluded that it was in fact the President and Palmer, rather than the Department of Labor, who constituted the menace to American liberty. ${ }^{133}$ Within just a few months of the raids, calmer minds had prevailed and public policy had altered course.

This period of abnormal invasion of individual liberties went into remission with the end of the Red Scare. ${ }^{134}$ The Espionage Act ceased to be in effect when the war with Germany was formally concluded in mid-1921, and the Sedition Act had been repealed shortly before. ${ }^{135}$ Two years later in 1923, the U.S. Pardon Attorney, in a communication with the Attorney General, recommended that the people who remained imprisoned based on convictions made under the Espionage and Sedition Acts be pardoned, opining that the evidence did not support the charges that had been against them. ${ }^{136}$ Soon thereafter, the sentences of the remaining prisoners were commuted. ${ }^{137}$

\section{Japanese Internment}

The typical examination of the Japanese Internment during World War II always seems to begin with the bombing of Pearl Harbor on December 7, 1941 - tagged with the well known phrase "a date which will live in infamy" 138 - as if this event was the sole causative factor in the United States' treatment of Japanese immigrants and their descendants during the war. The real story begins much earlier.

The first Japanese immigrants came to Hawaii and the United States in the late nineteenth ${ }^{139}$ and early twentieth centuries as agricultural laborers, ${ }^{140}$

129. HoYt, supra note 125 , at $115-17$.

130. GoLDSTEIN, supra note 85, at 159-60.

131. Id. at 160 .

132. Id.

133. Wiecek, supra note 120 , at 391.

134. GOLDSTEIN, supra note 85 , at 139. REDISH, supra note 34 , at 51 .

135. GOLDSTEIN, supra note 85 , at 172.

136. KoHN, supra note 83, at 20.

137. Id.

138. Franklin D. Roosevelt, Asking Congress to Declare War Against Japan (1941), available at $\mathrm{http} / / / \mathrm{www}$.law.ou.edu/ushistory/infamy.shtml (last visited Dec. 22, 2007).

139. Keith Aoki, No Right to Own?: The Early Twentieth-Century "Alien Lad Lands" as a Prelude to Intermment, 19 B.C. THIRD WORLD L.J. 37, 45 (1998).

140. John Schelhas, Race, Ethnicity, and Natural Resources in the United States: A Review, 42 NAT. RESOURCES J. 723, 734 (2002). 
filling a labor niche created by a coinciding shift in focus among farmers of the West Coast to more labor-intensive crops. ${ }^{141}$ Although the local population initially welcomed the expansion of the labor pool, ${ }^{142}$ it quickly became less hospitable as the Japanese immigrants began climbing the economic ladder, purchasing their own land, and directly competing with white farmers, many of whom had previously been the immigrants' employers. ${ }^{143}$ In the time surrounding the First World War, the western states began enacting legislation, now collectively known as the Alien Land Laws, which prohibited the ownership of real property by "aliens ineligible to citizenship," which included first generation Japanese immigrants. ${ }^{144}$ Though the legislation itself was framed in racially neutral terms, voter pamphlets candidly explained that the purpose of these laws was "to drive the Japanese immigrants out of their agricultural holdings." ${ }^{145}$ These laws succeeded in causing the dramatic decline of Japanese-owned land between 1920 and $1925 .{ }^{146}$ The Alien Land Laws, along with the Immigration Act of 1924, which prevented further immigration from Eastern Europe, Southern Europe, and Japan, were part of the larger antiimmigrant fervor that gripped America in the $1920 \mathrm{~s} .{ }^{147}$ However, these laws were not capable of barring land ownership among second-generation Japanese immigrants, who were American citizens by virtue of being born on US soil. ${ }^{148}$ As such, those among the first wave of immigrants did their best to transfer what they owned to their children. ${ }^{149}$

In the wake of Pearl Harbor, anti-Japanese sentiment resurfaced and it pressed its attack for the second time. In 1942, an article published in the nationally circulated Saturday Evening Post illustrated local sentiment when it quoted the secretary of the Salinas Vegetable Grower-Shipper Association as saying:

We're charged with wanting to get rid of the Japs for selfish reasons. We do. It's a question of whether the white man lives on the Pacific Coast or the brown men. They came into this valley to work, and they stayed to take over .... They undersell the white man in the markets.... They work their women and children while the white farmer has to pay wages for his help. If all the Japs were removed tomorrow, we'd never miss them in two weeks, because the white farmers can take over and produce everything the Jap grows. And we

141. Aoki, supra note 139 , at 45.

142. Id. at 52 .

143. Id. at 53. See also Schelhas, supra note 140 , at 734.

144. Aoki, supra note 139 , at 38 .

145. Schelhas, supra note 140 , at 734 .

146. Aoki, supra note 139, at 59 .

147. Id. at 62.

148. Id. at 51-52. See U.S. ConsT. amend. XIV, $\S 1$.

149. Aoki, supra note 139, at 63 . 
don't want them back when the war ends, either. ${ }^{150}$

Government action, once it began, was swift. On February 19, 1942, President Roosevelt issued Executive Order 9066, giving the Secretary of War a broad mandate for the strategic control of US territory:

I hereby authorize and direct the Secretary of War, and the Military Commanders whom he may from time to time designate, whenever he or any designated Commander deems such action necessary or desirable, to prescribe military areas in such places and of such extent as he or the appropriate Military Commander may determine, from which any or all persons may be excluded, and with respect to which, the right of any person to enter, remain in, or leave shall be subject to whatever restrictions the Secretary of War or the appropriate Military Commander may impose in his discretion. ${ }^{15}$

Shortly thereafter, on March 21, Congress passed an act making it a misdemeanor to knowingly disregard the restrictions made by military commanders pursuant to the President's executive order, ${ }^{152}$ after thoroughly examining the executive's intent to evacuate "persons of Japanese ancestry, citizens as well as aliens," which the Supreme Court later found to have been a ratification of Executive Order $9066{ }^{153}$ By May, military orders had provided the groundwork necessary for internment. ${ }^{154}$ General Dewitt, who commanded the Western Defense Command, was quoted as saying:

I don't want any Jap back on the Coast. ... There is no way to determine their loyalty. . . . It makes no difference whether the Japanese is theoretically a citizen--he is still a Japanese. Giving him a piece of paper won't change him. . . . I don't care what they do with the Japs as long as they don't send them back here. A Jap is a Jap. ${ }^{155}$

Gathered in relocation centers ostensibly for the purpose of being relocated into the interior of the country, Japanese Americans never went anywhere. ${ }^{156}$ That was because the Governors of the interior states refused to

150. Korematsu v.United States, 323 U.S. 214, 239 n. 12 (1944) (Murphy, J., dissenting).

151. Exec. Order No. 9066, 7 Fed. Reg. 1407 (1942).

152. Approval of military orders, 56 Stat. 173 (1942).

153. Hirabayashi v. United States, 320 U.S. 81, 90-91 (1943).

154. See Jerry Kang, Denying Prejudice: Internment, Redress, and Denial, 51 UCLA L. Rev. 933, 951 (2004).

155. Id. at 987 (footnote omitted).

156. Id. at 940 . 
accept them, apparently due to local prejudice. ${ }^{157}$ Wyoming's governor went so far as to say that his constituents had "a dislike of any Orientals, and simply [would] not stand for being California's dumping ground." He said that if Japanese Americans resettled in Wyoming, "[t]here would be Japs hanging from every pine tree."158 Utah's governor suggested that they be put into camps as forced labor. ${ }^{159}$

Interment was a reality by the time the first case involving internees reached the Supreme Court; ${ }^{160}$ however, while the Court chose to grant certiorari, it seems to have delayed its decisions so as not to conflict with the will of the political branches, ultimately doing nothing to stand in opposition to the internment of so many people. In hearing the internment cases, the Court exercised a style of decision making sometimes called "minimalism," an approach that "say[s] no more than necessary to justify an outcome, and leav[es] as much as possible undecided." ${ }^{\prime 61}$ In its decisions, the Court segmented the relevant issues (curfew, exclusion, and relocation), addressing the least controversial issue presented and ignoring the others. ${ }^{162}$ In so doing, it "obscure[d] its own agency" and thus its role in what took place. ${ }^{163}$

An activist named Gordon Hirabayashi brought the first interment case before the Court ${ }^{164}$ in an attempt to challenge interment in its entirety. ${ }^{165}$ Hirabayashi had been convicted of violating two military orders - one controlling the curfew, and the other exclusion - and received two concurrent sentences. ${ }^{166}$ The Court, anxious to avoid the possibility of opening review to the entire internment process, declined to address exclusion. ${ }^{167}$ Instead, it upheld the curfew, and since Hirabayashi had been given a concurrent sentence, averred that no reason existed for the Court to address his second conviction for exclusion. ${ }^{168}$

The next important case before the Court was Korematsu v. United States. ${ }^{169}$ Although the Korematsu and Hirabayashi cases were certified to the

157. Mark D. Friedman, Say "Cheese." Uncle Sam Wants Your Photograph and Fingerprints or You Are Out of Here. Does America Have A Peace Time Constitution in Danger of Being Lost?, 30 Nova L. REV. 223, 239 (2006).

158. Craig Green, Wiley Rutledge, Executive Detention, and Judicial Conscience at War, 84 WASH. U. L. REV. 99, 124 n. 118 (2006).

159. Id.

160. 97,000 people were held in assembly centers by June, 1942. In November, they were moved to "relocation camps," where they would remain interned. Kang, supra note 155, at 94041. Hirabayashi came before the court in June, 1943. See infra note 165.

161. Kang, supra note 154 , at 966 (citing CASS R. SUNSTEIN, ONE CASE AT A TIME: JUdiCLAL MINIMALISM ON THE SUPREME COURT 3 (1999)).

162. Id. at 944 .

163. Id. at 955 .

164. Hirabayashi v. United States, 320 U.S. 81 (1943).

165. Kang, supra note 154 , at 945.

166. Friedman, supra note 157 , at 241.

167. Kang, supra note 154 , at 945 .

168. Id. at 945. See also Friedman, supra note 157, at 241.

169. Korematsu v. United States, 323 U.S. 214 (1944). 
Supreme Court at the same time, the Court used procedural mechanisms to delay deciding Korematsu for about a year and a half. ${ }^{170}$ By that time, the military was busy mothballing the interment camps and sending the detainees home, so there was no risk of the Court interfering with the other two branches. ${ }^{171}$ In making its decision, the Court again segmented the issues to avoid addressing the broader issue of internment, instead isolating the issue of exclusion. ${ }^{172}$ Although the exclusion order was a fundamental part of the resulting internment, the Court went to great pains to characterize it as a wholly separate issue. ${ }^{173}$ As such, the Court reasoned that the remainder of the internment regime was beyond the scope of the case at hand, while simultaneously legitimizing the government's rational of military necessity. ${ }^{174}$ Later, we shall see that the Court already had good reason to believe that the rationale of military necessity, and the denial that exclusion was founded upon racist motives, were both false.

The Court finally addressed the issue of internment in Ex parte Endo, ${ }^{175}$ though it declined to review the case on constitutional grounds. ${ }^{176}$ First, the court sanctioned the internment program, saying that "temporary detention" might be a legitimately implied part of the authorized exclusion program. ${ }^{177}$ Second, it absolved both the President and Congress of the internment debacle by characterizing internment as a plan exclusively of the War Relocation Authority (WRA), ${ }^{178}$ the agency responsible for the administration of relocation, despite being aware that Congress had received testimony and held hearings about the mass detainment that was taking place and had continued to give the WRA annual appropriations to maintain its camps. ${ }^{179}$ To exonerate Congress in this way, the Court used a means of analysis completely at odds with the reasoning used to authorize curfews in Hirabayashi, where the Court had reasoned that testimony about curfews before Congress had been sufficient to suggest that Congress intended to authorize curfews. ${ }^{180}$

The convictions of Gordon Hirabayashi and Toyosaburo Korematsu were later overturned under a writ of coram nobis ${ }^{181}$ after historians discovered that the executive branch had suppressed factual evidence during the internment

170. Kang, supra note 154 , at $949-50$.

171. Cole, supra note 61 , at 2575.

172. Kang, supra note 154 , at $951-52$.

173. See id. at 951-52.

174. Id. at $952-54$.

175. Ex parte Endo, 323 U.S. 283 (1944).

176. Friedman, supra note 157, at 241-42.

177. Kang, supra note 154 , at 960 .

178. Id. at $959-60$.

179. Id. at $961-62$.

180. Id. at 963 .

181. BlaCK's Law Dictionary (8th ed. 2004) ("coram nobis, n. 2. A writ of ertor directed to a court for review of its own judgment and predicated on alleged errors of fact. -- Also termed writ of error coram nobis; writ of coram nobis."). 
cases. ${ }^{182}$ For example, the prosecution failed to alert the Supreme Court that General DeWitt had admitted to the Department of War that he did not regard speedy action against the Japanese population as necessary, and that several government agencies had discounted the idea that the group posed any threat (e.g. the "FBI had concluded that the call for evacuation was based primarily upon public and political pressure, not good data"). ${ }^{183}$ The courts ultimately overturned the convictions because of the prejudice that these omissions evoked in the Court. ${ }^{184}$ The problem with this conclusion is that the internment Court was not ignorant of these facts; during the trial it either received this precise information or something comparable to it. ${ }^{185}$ As the Court was independently aware of this evidence, the decision could hardly have been prejudiced by the prosecution's omission of it.

During the war, about 100,000 people were taken from their homes and put into internment camps, ${ }^{186}$ about 70 percent of whom were US citizens. ${ }^{187}$ Many were forced to sell their homes, businesses, ${ }^{188}$ and other property, suffering substantial loss. ${ }^{189}$ Until $1988,{ }^{190}$ the only compensation paid by the government for these losses was provided by the Japanese-American Evacuation Claims Act of 1948 , which paid a maximum of $\$ 2500$ in damaged per claim. $^{191}$

\section{The McCarthy Era}

The seeds for the McCarthy Era were planted before the Second World War, and were perhaps themselves part of the aftershocks from the Red Scare. Between 1927 and 1939, the American communist movement saw a massive resurgence. ${ }^{192}$ Benefiting politically from both the Great Depression and the rise of fascism in Europe, it managed to achieve "a position of some influence in American public life." composed of both businessmen and conservative politicians, had not gone away. ${ }^{194}$ In ominous tidings of what was to come, the 1930's anticommunist movement had largely moved away from its previous anti-immigrant orientation to one of partisan politics, attacking the New Deal, the power of the federal

182. Kang, supra note 154 , at $934-35$.

183. Id. at $977-78$.

184. Id. at $985-86$

185. Id. at $987-92$.

186. Green, supra note 158 , at 125.

187. Kang, supra note 154 , at 940.

188. Friedman, supra note 157 , at 240.

189. Schelhas, supra note 140 , at 735 .

190. Eric L. Muller, Fixing a Hole: How Criminal Law Can Bolster Reparations Theory,

47 B.C. L. REv. 659, 671 (2006).

191. Aoki, supra note 139 , at 64 .

192. Wiecek, supra note 120 , at 394.

193. Id. at 394-395.

194. Id. at 397. 
government, and Democrats that they labeled "soft on Communism.",195 This would later prove to be an effective attack on the Democratic Party, which seemingly could only be ameliorated by adopting a focus of equal animosity to the communist movement. ${ }^{196}$

This tension nearly reached a head with World War I. Along with reenacting the Espionage Act of 1917, in 1940 Congress passed the Smith Act, ${ }^{197}$ the country's first peacetime sedition law. ${ }^{198}$ In addition to making it illegal to advocate the desirability of overthrowing the government of the United States by force or violence, the Smith Act also made it illegal to be a member of an organization advocating such a position. ${ }^{199}$ With the outbreak of war a few months later, the government began limited efforts to prosecute dissidents on both the Right and the Left - fascists and communists. ${ }^{200}$ Soon, however, the Soviet Union became an important military ally to the United States, and the prosecution of individuals from the Left quickly abated. ${ }^{201}$ In fact, the war ultimately proved to be a benefit for the domestic communist movement. The American Communist Party, whose membership soared to over 75,000 during this period, strongly backed the war effort, and the public began to look upon the Soviet Union more favorably than it ever had before. ${ }^{202}$

Foreign affairs only provided a temporary stay of prosecution; things changed as the relationship between the new superpowers became less congenial. ${ }^{203}$ As the months passed, it became increasingly clear that the Russians did not plan to withdraw their influence from the countries of Eastern Europe that they had rolled through on their push to Berlin. In retrospect, it has been argued that Russia merely intended to maintain a buffer between itself and the states of Europe, because it had been invaded by western powers three times in twentieth century and had suffered over 30 million casualties in the Second World War alone. However, the Soviets, sitting on the brink of war ravaged Western Europe with the most powerful array of land forces in the world, were the subject of great fear in the West. The American response was to buttress the military capacity of Western Europe (and later countries in the Middle East, Central Asia and East Asia) in an effort to contain potential Soviet aggression, a strategy known as the Truman Doctrine. Over time Europe began to bifurcate under the influence of the two powers: economically, between the Marshall

195. Id.

196. Id.

197. Smith Act, ch. 439,54 Stat. 670 (1940).

198. GoLDSTEIN, supra note 85 , at 245.

199. Id. Alternately known as the Alien Registration Act, it also required all aliens above the age of 14 to register with the federal government. About 5 million people were registered. Lewis M. Stevens, The Life and Character of Earl G. Harrison, 104 U. PA. L. REv. 591,597 (1956).

200. Wiecek, supra note 120 , at 402.

201. Id. at 403.

202. GOLDSTEIN, supra note 85 , at 287-89.

203. See id. at 289-96. 
Plan, the Bretton Woods regime and the Comecon; militarily, between NATO and the Warsaw Pact; and politically, between the marginalization of noncommunists in Eastern Europe and the marginalization of communists in Western Europe. ${ }^{204}$ If this grinding standoff was tinder for the public anxiety that was sparked by events such as the Berlin Blockade and the Korean War, then domestic politics were gasoline to the flame. ${ }^{205}$

America was not in the grip of fear at the conclusion of the war. Even with the Soviets occupying Eastern Europe, "42 percent of Americans believed that U.S.-Soviet relations would improve, and only 19 percent felt they would worsen." 206 This made things difficult for the Truman Administration; before it chose the stance it would take toward the Soviet Union, the Democratic leftwing was critical of any policy that was overly aggressive towards the Soviets while Republicans were critical of any policy seen as being soft on communism. ${ }^{207}$ Truman's solution was two fold: he took an aggressive policy toward the Soviets abroad, which stole the wind from the Right's sails by essentially adopting its position, and labeling the opposition to his policy at home as part of a subversive plot, dramatically undermining the left wing of his party. ${ }^{208}$

Similar activities took place in Congress. In the House of Representatives, the House Un-American Activities Committee (HUAC) became a standing committee in $1945 .^{209}$ Its authorizing resolution gave the committee a mandate to investigate propaganda in the United States; particularly that which attacked the form of government "guaranteed by the Constitution," and all related questions that would aid Congress in forming remedial legislation. ${ }^{210}$ This reflected the constitutional duty of Congressional committees to limit the scope of their investigations to gathering information necessary for making legislation. ${ }^{211}$ However, since the time of its initial creation in 1938 as a special committee, the members of HUAC were candid about their self-perceived role as investigating and exposing "subversives" in government and private employment in order to subject them to both public shame and to discrimination from employers, i.e. blacklisting. ${ }^{212}$ In 1947, HUAC went so far as to officially announce an eight-point program designed to identify and expose communists and their sympathizers in the federal government. ${ }^{213}$ While these activities were politically beneficial to the committee's members, who traveled around the country to hold their

204. See Paul Kennedy, The Rise and Fall of the Great Powers $480-492$ (1989).

205. GoLDSTEIN, supra note 85 , at 292-99.

206. Id. at 296.

207. Id. at 296-99.

208. Id.

209. Id. at 292.

210. REDISH, supra note 34 , at 37.

211. Watkins v. United States, 354 U.S. 178, 187 (1957). REDISH, supra note 34, at 38.

212. Barenblatt v.United States, 360 U.S. 109, 153-158 (1959) (Black, J., dissenting).

213. GOLDSTEIN, supra note 85 , at 296. 
investigations, often during election years and in their own districts, ${ }^{214}$ it was quite beyond the scope of constitutional committee activity. ${ }^{215}$ Though the Supreme Court was presented with this separation-of-powers issue in cases such as Watkins v. U.S., ${ }^{216}$ and though it noted at various points that the committee was performing a non-legislative function which negatively impacted on First Amendment and due process rights, the Court never chose to take its opportunity to invalidate the committee's investigatory authority. ${ }^{217}$

While events in the House of Representatives played their part in affecting American public opinion, the real political showdown took place in the Senate. By the time Senator Joseph McCarthy rose to prominence in America, anti-communism was already a major issue, and had been used by both parties to further their political agendas. ${ }^{218}$ Buoyed by the Korean War, the Rosenberg prosecution, and Mao's final triumph in China, McCarthy famously took the reins of strategy for the Republican Party, devastating political rivals with allegations of "communist infiltration" and racing around the country to support friendly politicians; indeed, he received more invitations to speak "than all other republican spokesmen combined." ${ }^{219}$ Meanwhile, flagging Democrat candidates also attempted to use red scares in their election campaigns. $^{220}$

The President and members Congress, acting primarily to advance their individual political agendas, worked together to help fuel the country's hysteria. $^{221}$ The issue of anti-communism slowly changed from focused criticism on immigration and unionism in the early part of the century to a crisis upon which the country's survival seemed to hinge. ${ }^{22}$ Fear of communism gradually increased, to the point in 1954 where an estimated $81 \%$ of Americans felt that communists posed a significant danger to the country. ${ }^{223}$ Any position on foreign policy advocating anything less than the strongest possible opposition to communism was deemed suspect. ${ }^{224}$ Congress went so far as to pass the Internal Security Act of $1950,{ }^{225}$ which posited the belief of an international communist conspiracy intended to create world wide dictatorship, and empowered the Attorney General in a time of national emergency to detain anyone that he had reasonable ground to believe "probably will engage in, or

214. Id. at $345-46$.

215. Watkins, 354 U.S. at 187 . REDISH, supra note 34 , at 38.

216. Watkins, 354 U.S. at 178.

217. REDish, supra note 34 , at $40-41$.

218. GOLDSTEIN, supra note 85 , at 320 .

219. Id. at $320-25$.

220. Id.

221. Id. at 320-21.

222. Wiecek, supra note 120 , at 400 .

223. Christina E. Wells, Fear and Loathing in Constitutional Decision-Making, 2005 WIs.

L. REV. 115, 134 (2005).

224. GolDSTEIN, supra note 85 , at 371 .

225. Internal Security Act of 1950, 64 Stat. 987 (alternately known as the McCarran Act and the Emergency Detention Act). 
conspire with others to engage in, acts of espionage or sabotage.,"226 Coming on the heels of Japanese internment during World War II, this statute provided for the mass roundup of individuals based on the mere prediction of future illegal activity, ${ }^{227}$ forbidding access to the courts by those detained. ${ }^{228}$ It was later repealed in 1971 due to the concern that it could "become an instrumentality for apprehending and detaining citizens who hold unpopular beliefs and views" which reflected the radical extent to which it had empowered the government. $^{229}$

Within this context, the executive resumed prosecuting members of the communist party. ${ }^{230}$ Though the political capital gained through these prosecutions was rooted in the image of combating espionage, spying was not the legal basis for most of these prosecutions; ${ }^{231}$ rather, the government made most of its prosecutions under the Smith Act, ${ }^{232}$ convicting people for being members of the communist party. ${ }^{233}$ Since the Smith Act directly conflicted with freedom of speech and freedom of association, ${ }^{234}$ the question of its constitutionality was quickly appealed to the Supreme Court after twelve leaders of the communist party were convicted in 1948 for their membership in the party. ${ }^{235}$ While the Court used the clear and present danger test in reviewing the law's validity, it expanded the scope of the elements of the test dramatically so that the law could be upheld. ${ }^{236}$ It first allowed the "present" requirement to be satisfied by the indication that a rebellion would occur "as speedily as circumstances would permit."237 Doing so amounted "to nothing more than a complete rejection of the relevance of that prong of the test.",238 The Court then gutted the danger requirement, allowing it to be satisfied by the party being "highly organized," and noting the turmoil that was taking place elsewhere in the world. ${ }^{239}$ As a result, rather than gauging the speech "in terms of the probability of success, or the immediacy of a successful attempt," the Court expanded the test so that the government could "punish speech even when it is unlikely to bring about unlawful action, provided the unlawful action itself [would be] sufficiently 'grave.",240

226. Wiecek, supra note 120 , at $426-427$.

227. GOLDSTEIN, supra note 85 , at 323.

228. Wiecek, supra note 120 , at 426.

229. Sarah A. Whalin, National Security Versus Due Process: Korematsu Raises its Ugly

Head Sixty Years Later in Hamdi and Padilla, 22 GA. ST. U. L. REv. 711, 718 (2006).

230. REDISH, supra note 34 , at 81.

231. Id. at 6.

232. Smith Act, 54 Stat. 670 (1940).

233. REDISH, supra note 34 , at 79-80.

234. See supra notes 197-199 and accompanying text.

235. Dennis v. United States, 341 U.S. 494 (1951).

236. See REDISH, supra note 34, at 91-92. Barnum, supra note 111, at 276.

237. Dennis, 341 U.S. at 509-510.

238. See REDISH, supra note 34, at 91-92.

239. Dennis, 341 U.S. at 510-511. See also REDISH, supra note 34, at 91-92.

240. Barnum, supra note 111, at 277. 
After this green flag, the government increased its prosecutions. The Truman Administration began targeting second-string leaders of the communist party, indicting sixty-eight people under the Smith Act in 1951 and $1952 .^{241}$ The trend continued under Eisenhower, with forty-two indicted from 1953 to $1956 .^{242}$ When the Supreme Court finally began to overturn convictions made under the Smith Act in 1957, closing the door it had opened for prosecutors six years prior, the facts in the overturned cases were little different from those in the initial cases. ${ }^{243}$

\section{B. The United Kingdom}

\section{The British System of Emergency Power}

The first major difference between the British and American systems of government is that the United Kingdom lacks a written constitution. Although the United Kingdom is guided by centuries of practice and tradition, there are no Articles I or II to serve as a foundation for identifying the delineated powers of government, which tends to make the balance between executive and legislature much more flexible.

Contrary to the common misperception in America, the monarchy continues to be a valid legal entity in the government of the United Kingdom. Today, the Crown retains several prerogatives, ${ }^{244}$ including the right to declare "war, peace, or neutrality" 245 however, royal powers have been highly constrained since the final triumph of parliamentary supremacy in the late seventeenth century. ${ }^{246}$ As a practical matter, royal prerogatives are exercised according to the wishes of Parliament, ${ }^{247}$ in that they may be limited legislatively, and in practice are only exercised on the advice of the Prime Minster. ${ }^{248}$ Indeed, the Prime Minster himself is beholden to Parliament

241. GOLDSTEIN, supra note 85 , at 332.

242. Id. at 339.

243. Yates v. United States, 354 U.S. 298, 318-19 (1957) (reinterpreting the Smith Act, determining that it had not in fact been passed with the intent to punish the advocacy of an abstract doctrine - in complete contradiction of the Court's decision in Dennis in 1951). See also Corey Robin, Fragmented State, Pluralist Society, 69 Mo. L. REV. 1061, 1079 (2004).

244. BLACK's LAW DictionaRy (8th ed. 2004) ("prerogative, n. An exclusive right, power, privilege, or immunity, usu. acquired by virtue of office").

245. Tarnopolsky, supra note 58, at 198. See also Louis Fisher, Lost Constitutional Moorings: Recovering the War Power, 81 IND. L.J. 1199, 1201 (2006).

246. Robert C. Sarvis, Legislative Delegation and Two Conceptions of the Legislative Power, 4 PIERCE L. REV. 317, 318-320 (2006) (parliamentary supremacy is a result of the Glorious Revolution, in which Parliament played an active role in replacing James II with William III).

247. Tarnopolsky, supra note 58, at 198.

248. Andrew C.S. Efaw, Free Exercise and the Uniformed Employee: A Comparative Look at Religious Freedom in the Armed Forces of the United States and Great Britain, 17 COMP. LAB. L.J. 648, 664 (1996). 
because, unlike the President of the United States, who can only be removed by impeachment, ${ }^{249}$ the Prime Minster can be removed at any time by a vote of no confidence. $^{250}$ This is another manifestation of the doctrine of parliamentary supremacy, the doctrinal basis of the United Kingdom's political system, which defines the legislature as the foremost power in government, unrestrained in its actions; it may make or unmake any law, and faces no legal restriction on its ability to do so. ${ }^{251}$ It should be noted though that this arrangement is a matter of convention, i.e. non-legal tradition, rather than "law."252 Furthermore, Parliament has lacked even the procedural impediment of bicameralism for almost a century, because as a result of the Parliament Acts ${ }^{253}$ the House of Commons no longer requires the assent of the House of Lords to pass legislation. ${ }^{254}$

Parliamentary supremacy has important ramifications for the judiciary. The origin of the American Bill of Rights can be found in England's tradition of philosophical thought about the rights of the individual, ${ }^{255}$ exemplified in such documents as the Petition of Right ${ }^{256}$ and the English Bill of Rights. ${ }^{257}$ While such enunciation of rights may have the political impact of impressing respect for them in public opinion, ${ }^{258}$ "no court of law or other body in the United Kingdom has the constitutional right to challenge an act of parliament."259 In evaluating an act of Parliament, the power of the courts is limited to interpreting Parliament's intent. ${ }^{260}$ As the House of Lords stated in an evaluation of government emergency powers:

in the constitution of this country there are no guaranteed or absolute rights. The safeguard of British liberty is in the good

249. U.S. CONST. art. II, $\S 4$.

250. John C. Reitz, Political Economy and Separation of Powers, 15 TRANSNAT'L L. \& CONTEMP. PROBS. 579, 593 (2006).

251. Michael L. Principe, Albert Venn Dicey and the Principles of the Rule of Law: Is Justice Blind? A Comparative Analysis of the United States and Great Britain, 22 LoY. L.A. INT'L \& COMP. L. REv. 357, 360-361 (2000).

252. Adam Tomkins, The Republican Monarchy Revisited, 19 CONST. COMMENT. 737, 74247 (2002).

253. Parliament Act, 1911, 1 \& 2 Geo. 5, c. 13. Parliament Act, 1949, 12, 13 \& 14 Geo. 6, c. 103.

254. Jeremy Waldron, The Internal Point of View in Law and Ethics, 75 FORDHAM L. REV. 1697,1702 n. 20 (2006).

255. See Michael Kent Curtis, No State Shall Abridge 64 (1986).

256. The Petition of Right (1628), available at http://www.constitution.org/eng/petright.htm (last visited Dec. 22, 2007).

257. The English Bill of Rights (1689) (claiming the basic rights of Englishmen include the existence of independent courts, freedom to petition, freedom to bare arms, freedom of speech in Parliament, and freedom from cruel and unusual punishment), available at http://www.yale.edu/lawweb/avalon/england.htm (last visited Dec. 22, 2007).

258. CURTIS, supra note 255 , at 21.

259. Tarnopolsky, supra note 58, at 198.

260. BONNER, supra note 13 , at 52 . 
sense of the people in the system of representative and responsible government which has been evolved. ${ }^{261}$

In the United States, when Congress passes legislation treading upon the grounds of inalienable rights, the legitimacy of the legislation requires five Supreme Court Justices to be on board. Parliament has no such limitation.

This status of the courts in the United Kingdom, compared to those in the United States, represents a doctrinal split in judicial philosophy. In early seventeenth century England, when "the common law itself supplied the rules now described as constitutional," ${ }^{262}$ Sir Edward Coke, the chief justice of the Court of Common Pleas, famously stated:

And it appears in our books, that in many cases, the common law will controul Acts of Parliament, and sometimes adjudge them to be utterly void: for when an Act of Parliament is against common right and reason, or repugnant, or impossible to be performed, the common law will controul it, and adjudge such Act to be void. ${ }^{263}$

In colonial American, this rule was rephrased to say: "[a]n act contrary to the constitution is void."264 Though this doctrine was effectively dead in England by the time of the American Revolution, ${ }^{265}$ it lived on in the colonies, with Chief Justice John Marshall ultimately introducing the concept into the federal judiciary in Marbury v. Madison. ${ }^{266}$

The constitution is either a superior, paramount law, unchangeable by ordinary means, or it is on a level with ordinary legislative acts, and like other acts, is alterable when the legislature shall please to alter it. If the former part of the alternative be true, then a legislative act contrary to the constitution is not law: if the latter part be true, then written constitutions are absurd attempts, on the part of the people, to limit a power, in its own nature illimitable.

Certainly all those who have framed written constitutions contemplate them as forming the fundamental and paramount law of the nation, and consequently the theory of every such government must be, that an act of the legislature, repugnant

261. Liversidge v. Anderson, [1942] A.C. 206 (H.L.), available at http://uniset.ca/other/cs5/1942AC206.html (last visited Dec. 22, 2007).

262. ORTH, supra note 19 , at 99.

263. Id. at $18-20$.

264. Id. at 20.

265. See id. at 25.

266. Marbury v. Madison, 5 U.S. 137 (1803). 
to the constitution, is void. ${ }^{267}$

Some scholars have speculated that the absence of judicial review and a binding list of fundamental rights in the United Kingdom has caused the government to afford itself more power than it otherwise would have during times of emergency. ${ }^{268}$

Somewhat paradoxically, while the legislature of the United Kingdom is supreme in its authority, it has a habit of ceding its authority to the executive. Whereas the U.S. Constitution limits Congress in the degree to which it may delegate authority to the President with the prescription "[a]ll legislative Powers herein granted shall be vested in a Congress of the United States," ${ }^{269}$ Parliament faces no such restriction. Further, when it delegates authority for emergency powers, it typically does so through means that marginalize the ability of the judiciary to scrutinize the executive's actions, such as by "fram[ing] discretionary powers in subjective terms, rather than in the objective terms which more clearly impart a judicially reviewable standard" and by being "rather vague as to the criteria governing the exercise of [that] power."270 With judicial scrutiny thus obviated, oversight of the executive's use of emergency power is left to the legislature. ${ }^{271}$ The effectiveness of Parliament's role as "watchdog," however, is somewhat limited. Though the power to legislate appears to give Parliament full control of emergency powers, "it is well known... that legislation is made elsewhere and legitimated in Parliament," that emergency legislation is often brought forward and passed quickly, and that it is rare for its key provisions to be amended. ${ }^{272}$ And further, although Parliament sometimes inserts provisions into enabling acts which require the Parliament to approve executive regulations before they take affect, or which allow Parliament to annul them later, ${ }^{273}$ a dramatic asymmetry of information exists between the government's executive actors and "the watchdogs" in regard to how the executive's powers are actually being used. ${ }^{274}$

\section{War Powers (The First and Second World Wars)}

It was no surprise to anyone when war came to the European continent in 1914; tensions had been building for a decade before the first shots were

267. Marbury, 5 U.S. at 177.

268. Dana Keith, In the Name of National Security or Insecurity?, 16 FLA. J. INT'L L. 405, 415 (2004).

269. U.S. CONST. art.I, § I. See Limitations on rule; permissible delegation, 16A AM. JUR. 2D Constitutional Law $\$ 297$ (2006).

270. BONNER, supra note 13, at 53-54.

271. John Eaves, JR., Emergency Powers and the Parliamentary Watchdog 14 (1957).

272. BONNER, supra note 13 , at 37-38.

273. Tony Bunyan, The Political Police in Brttain 55 (2d ed. 1976).

274. BONNER, supra note 13 , at 49. 
fired. ${ }^{275}$ Shortly after the outbreak of hostilities, Parliament passed the Defence of the Realm Act 1914 (DORA) ${ }^{276}$ without debate. ${ }^{277}$ DORA allowed the executive to pass regulations with the force of law ${ }^{278}$ for the purpose of public safety and "the defence of the realm.",279 The regulations that were created gave the government extensive control over the economy; ${ }^{280}$ the power to detain individuals on the basis of "hostile origin or association," with 30,000 people ultimately being detained without trial; as well as the power to prohibit assemblies, clear areas, and impose curfews. ${ }^{281}$ During this time, the government also used DORA to constrain freedom of speech by punishing the causation of "mutiny, sedition, or disaffection" among the military or civilian population, and freedom of the press by prohibiting the publishing "of statements or reports likely to 'cause disaffection' or to 'prejudice the recruiting, training, discipline, or administration' of the military."282 Although DORA was not popular among the British people, ${ }^{283}$ popular opinion seemed to indicate the restriction on freedom was necessitated by the war with Germany. ${ }^{284}$

The Second World War was also seen on the horizon long before its arrival. ${ }^{285}$ Perhaps the primary difference for Britain in the time leading up to these conflicts was that prior to the First World War it had been in a superior position compared to its adversaries, ${ }^{286}$ whereas it entered the Second World War as the underdog. ${ }^{287}$ As such, it should be of little surprise that emergency regulations were again passed with only nominal debate ${ }^{288}$ - this time in the form of the Emergency Powers (Defence) Act 1939 (EPA 39). ${ }^{289}$ The executive was essentially given the same authority: to create regulations for the purpose of "public safety, the defence of the realm, the maintenance of public order, the efficient prosecution of the war, and the maintenance of supplies and services essential to the life of the community."

275. See KENNEDY, supra note 204, at 324-328.

276. Defence of the Realm Act, 4 and 5 Geo. V, c. 29.

277. EAVES, supra note 271, at 8-9.

278. Rachel Vorspan, Law and War: Individual Rights, Executive Authority, and Judicial Power in England During World War I, 38 VAND. J. TRANSNAT'L L. 261, 267 (2005).

279. EAVES, supra note 271, at 8-9.

280. Id.

281. Vorspan, supra note 278, at 270. Daniel Moeckli, The Selective "War on Terror": Executive Detention of Foreign Nationals and the Principle of Non-Discrimination, 31 BROOK. J. INr'L L. 495, 500 (2006).

282. Id. at 270.

283. EAVES, supra note 271 , at 8-9.

284. Vorspan, supra note 278, at 271-72. EAVES, supra note 263, at 8-9.

285. See KENNEDY, supra note 203, at 433-39.

286. Id. at 332-33.

287. Id. at $439-41$.

288. BONNER, supra note 13 , at 38.

289. Emergency Powers (Defence) Act 1939, 2 and 3 Geo. 6, c. 62.

290. EAVES, supra note 271, at 15-16. 
internment was again practiced, with about 28,000 people being interned. ${ }^{291}$

Parliament did little to constrain the executive in its exercise of legislative power under DORA. The enabling statute contained no specific provisions requiring Parliament to approve, or allowing it to annul, regulations issued by the executive. ${ }^{292}$ Further, it was written to remain in effect until the executive declared hostilities to have ended, ${ }^{293}$ which did not occur until $1920,{ }^{294}$ a flaw which would not be repeated in future legislation. ${ }^{295}$ Regardless, the judiciary was able to exercise a degree of control over the executive through the language of DORA. ${ }^{296}$ The courts interpreted it to have created an objective standard for the executive to follow in creating regulations for the defense of the realm, in theory allowing regulations to be struck down if they were found to fall outside of Parliament's mandate. ${ }^{297}$

In the EPA 39, Parliament expanded its watchdog function, while circumscribing the role of the courts. Regulations came into force automatically, and had the power to amend or repeal existing laws, but either house of Parliament could annul a regulation within the first 28 sitting days after its issuance. ${ }^{298}$ Further, rather than allowing the executive to determine when these emergency powers would cease to be in effect, the act was set to expire after twelve months if it was not renewed, though it wasn't actually repealed until 1959. ${ }^{299}$ This time, the judiciary's influence was limited because the legislation was framed in a subjective standard, merely requiring the executive to show that its regulations appeared to be necessary or expedient. ${ }^{300}$ This measure may have been unnecessary; because even when the courts were in a position to wield influence over the executive they exhibited a noticeable deference, apparently with the rationale that the necessities of war justified the expansion of government power at the expense of individual rights. ${ }^{301}$ The judiciary event went so far as to interpret legislative mandates in a broader manner than would normally apply in order to support the executive's aims. ${ }^{302}$

\section{Labor Emergencies}

In the early twentieth century, Great Britain was home to an increasingly powerful labor movement. Particularly strong were the country's coal miners, railroad workers, and transportation workers, who had formed a loose affiliation

291. Moeckli, supra note 281 , at 500 .

292. BONNER, supra note 13 , at 41.

293. Tarnopolsky, supra note 58 , at 200.

294. BUNYAN, supra note 273, at 52.

295. BONNER, supra note 13 , at 41.

296. EAVES, supra note 271 , at 18.

297. Id.

298. BUNYAN, supra note 273, at 55. See also EAVES, supra note 271, at 18.

299. BunYaN, supra note 273, at 55. See also EAVES, supra note 271, at 18.

300. EAVES, supra note 271 , at 18.

301. See BONNER, supra note 13 , at 55-59.

302. Id. at 59 . 
known as the Triple Alliance. ${ }^{303}$ This perturbed government officials, who recognized that a strike by the alliance of unions had the potential to bring the country to a standstill. ${ }^{304}$ Further, in the shadow of the 1917 Russian Revolution, the government feared the social upheaval which could result from such a massive strike might lead to revolutionary turmoil in Britain. ${ }^{305}$ Since 1914 , the government had been able to use legislation such as DORA during labor emergencies, but as the war and access to those war powers began drawing to a close, Parliament began to look toward legislation which could be used for similar purposes during peacetime. ${ }^{306}$

Parliament ultimately passed the Emergency Powers Act 1920 (EPA $1920)^{307}$ to give the executive emergency power to forestall the inhibition of a community's access to the "essentials of life," 308 empowering the government to counter "major strikes, civil disorders and pre-revolutionary situations."309 The act was introduced by Parliament in the midst of a miners' strike, which spectators thought the railroad workers might soon join, making it "precisely the time when Parliamentary and public opinion was least able dispassionately to weigh up either its short-terms merits or long-term consequences." 310 However, as much as the EPA 1920 was demanded by the representatives of certain parts of the country, it faced substantial opposition from many other legislators. $^{311}$ The dramatic division in public sentiment is likely the reason why the emergency powers created were far less extensive than those afforded to the government during the wars in 1914 and $1939 .^{312}$

Under the EPA 1920, the executive was again vested with the power to create regulations after declaring a state of emergency, this time to "restore order and maintain supplies" whenever it appeared "to the government that the essential services of the country" were threatened by "any action [that] has been taken or is immediately threatened by any persons or body of persons." ${ }^{313}$ As was true in the later EPA 39, the subjective element of this prescription vastly diminished the potential scope for judicial review of the executive's actions. ${ }^{314}$ Parliament, however, perhaps having already learned its lessons from DORA, implemented several watchdog functions. Though it could not directly annul a regulation, any regulation which Parliament did not approve within seven days would have become void. ${ }^{315}$ Further, the whole bundle of regulations had to be

303. Id. at 224.

304. See id. at 224.

305. BUNYAN, supra note 273, at 10.

306. Id.

307. Emergency Powers Act, 10 \& 11 Geo. V, c. 55.

308. EAVES, supra note 271 , at 9.

309. BUNYAN, supra note 273 , at 52-53.

310. BONNER, supra note 13, at 39-40.

311. See EAVES, supra note 271, at 9.

312. See BONNER, supra note 13 , at 13.

313. BUNYAN, supra note 273 , at $52-53$.

314. See BONNER, supra note 13, at 234.

315. Id. at 43. 
renewed by Parliament every month. ${ }^{316}$ The criticism the bill faced during the debates over its passage also led its supporters to add explicit limits to the scope of the executive's rulemaking power. ${ }^{317}$ Accordingly, the government could not criminalize participation in a strike, it could not impose military or industrial conscription, and it could not "punish by fine or imprisonment without trial."318

Aside from those limitations, the executive had the power to suspend any law in order to achieve its goals. ${ }^{319}$ The regulations created by the government were mostly designed to allow soldiers to do civilian work, including the work of dockworkers, sewage workers, prison officers, etc. ${ }^{320}$ An amendment to the law in 1964 allowed the use of soldiers in agricultural work. ${ }^{321}$ Regulations were also used to expand police powers for stopping individuals, entering homes, searching, and arresting. ${ }^{322}$

The EPA 1920 was activated 12 times ${ }^{323}$ before it was replaced in 2004 by the Civil Contingencies Act (CCA) ${ }^{324}$ The CCA again allows the executive to create regulations, if it is "satisfied [the regulations are] appropriate for the purpose of preventing, controlling or mitigating an aspect or effect"325 of an emergency that "has occurred, is occurring or is about to occur." "326 This is clearly another set of subjective criteria, limiting supervision by the judiciary. Under this legislation, the term "emergency" encompasses war, terrorism, or any other event or situation that "threatens serious damage" in the form of loss of human life, human illness or injury, damage to property, the disruption of communication, transportation, the supply of food or fuel, etc. Parliament continues to play an important role because regulations will lapse after seven days if not approved, and may be annulled or amended subsequently. ${ }^{327}$

\section{Anti-Terrorism}

The British tradition of anti-terrorism legislation was spawned as a means of combating the Irish Republic Army (IRA), which remained the focus of this branch of law for over half a century.

The Prevention of Violence (Temporary Provisions) Act 1939 (PVA

316. BUNYAN, supra note 273 , at 53 .

317. BONNER, supra note 13 , at $39-40$.

318. Id. at 234-35. However, this limitation didn't necessarily preclude detention regarded as preventative rather than punitive. Id.

319. BUNYAN, supra note 273 , at 53 .

320. BONNER, supra note 13 , at 229-30.

321. Id. at 229.

322. Id. at 239.

323. Id. at 13 .

324. Civil Contingencies Act, 2004, c.36 (Eng.).

325. Id. \& 22.

326. Id. \$ 21.

327. Id. \& 27. 
39), ${ }^{328}$ the country's first piece of anti-terrorism legislation, was drafted in response to an IRA bombing campaign in England. ${ }^{329}$ Passed in July after four days of Parliamentary consideration, ${ }^{330}$ the new law had broad support ${ }^{331}$ which was buttressed by the fear that the IRA was being "actively stimulated" by the United Kingdom's wartime enemies on the continent. ${ }^{332}$ By that time, 66 people had already been arrested for their suspected participation in the 127 attacks which had occurred thus far. ${ }^{333}$

Unlike the previous examples of British emergency legislation examined in this Note, the PVA 39 did not give the executive the authority to create regulations. ${ }^{334}$ Instead, it enabled the executive to require foreigners to register with the government, to expel people from the country if reasonably satisfied the person "was engaged in the preparation or instigation of" an act of violence, or to prohibit that person's entry if reasonably satisfied that the person might be trying to enter "with a view to being so engaged." police to arrest people they "reasonably suspected" to be guilty of one of the terrorism-related offences created by the PVA 39, "of being subject to an expulsion or prohibition order, or of being concerned in the preparation or instigation of acts of violence to which the Act was directed." ${ }^{336}$ Although the PVA 39 was passed with the intention of being a short-term statute with a lifespan limited to two years if not renewed, ${ }^{337}$ and although the bombing campaign it was designed to combat ceased in March $1940,{ }^{338}$ Parliament kept it alive until $1954,{ }^{339}$ then resurrected the majority of its provisions less than twenty years later. ${ }^{340}$

Northern Ireland itself was subject to an additional statutory regime at this time ${ }^{341}$ known as the Civil Authorities (Special Powers) Act, ${ }^{342}$ which had been instituted in 1922 at the time of the Irish partition, ${ }^{343}$ with the intention of

328. Prevention of Violence (Temporary Provisions) Act, 1939, 2 \& 3 Geo. 5, c. 50 (Eng.).

329. BONNER, supra note 13 , at 14.

330. Id. at 38-39; Tm PAT COOGAN, The IRA: A History 97 (1994).

331. Donohue, supra note 12 , at 316 .

332. COOGAN, supra note 330 , at 97.

333. Id.

334. See BONNER, supra note 13 , at 168 .

335. Id. at 168 .

336. Id.

337. DONOHUE, supra note 12 , at 306.

338. COOGAN, supra note 330, at 97; BONNER, supra note 13 , at 14 .

339. DonohuE, supra note 12, at 306-07; see also Reuven Young, Defining Terrorism: the Evolution of Terrorism as a Legal Concept in International Law and its Influence of Definitions in Domestic Legislation, 29 B.C. INT'L \& CoMP. L. Rev. 23, 73 (2006).

340. DONOHUE, supra note 12 , at 307.

341. Colm Campbell, 'Wars on Terror' and Vicarious Hegemons, 54 INT'L \& CoMP. L.Q. 321,335 (2005). In fact, Northern Ireland has arguably been in a state of permanent emergency since its creation. Id.

342. Civil Authorities (Special Powers) Act, 1922, 12 \& 13 Geo. 5, c. 5 (N. Ir.).

343. Stephen J. Schulhofer, Checks and Balances in Wartime, 102 MICH. L. REv. 1906, 1936 (2004). 
only being in force for a year. ${ }^{344}$ This act gave the local executive authorities the power to establish regulations "as may be necessary for preserving the peace and maintaining order," hundreds of which were ultimately issued, ${ }^{345}$ and served as the legal basis for internment without trial in Northern Ireland multiple times ${ }^{346}$ by the early $70 \mathrm{~s}$, when a renewed IRA bombing campaign began in England. ${ }^{347}$ In 1971, internment powers were again established and were actively used until 1975, during which time almost two thousand people were detained without trial. ${ }^{348}$ Some detainees were subject to extreme interrogation techniques, such as being forced to stand in stress positions for hours, hooded, subject to loud noise, and were deprived of food, water and sleep, ${ }^{349}$ for the purpose of eliciting confessions and intelligence. ${ }^{350}$ It was also alleged the detainees were subject to beatings, electrical shocks, and the forcible administration of drugs. ${ }^{351}$

Soon thereafter, Parliament suspended the Northern Ireland Parliament, taking direct control of the region, ${ }^{352}$ and replaced the Special Powers Act ${ }^{353}$ with the Northern Ireland (Emergency Provisions) Act, 1973 (EPA 73) ${ }^{354}$ This new legislation did little to restrain the government's internment powers; ${ }^{355}$ rather, the significant change that it made was to introduce into Northern Ireland a system for trials known as the "Diplock Court."356 Used to try suspected terrorists, the two most notable features of this system were the absence of a jury and special rules of evidence; in particular, the courts allowed confessions obtained through "intensive interrogations" into evidence. ${ }^{357}$ At one point in time, confessions were the primary evidence relied upon in 90 percent of the cases heard before Diplock Courts. ${ }^{358}$ Other evidentiary changes in these courts included the infringement of the right to silence, the use of

344. Laura K. Donohue, Anti-Terrorist Finance in the United Kingdom and United States, 27 MiCH. J. INT'L L. 303, 325 n. 91 (2006).

345. Civil Authorities (Special Powers) Act $\S 1$; see also Laura K. Donohue, Terrorist Speech and the Future of Free Expression, 27 CARDOZO L. REV. 233, 256 (2005).

346. Moecki, supra note 281 at 503 n. 46. In 1922-24, 1938-45, and 1956-61. Id.

347. DONOHUE, supra note 12 , at 316 .

348. Michael P. O'Connor \& Celia M. Rumann, Into the Fire: How to Avoid Getting Burned by the Same Mistake Made Fighting Terrorism in Northerm Ireland, 24 CARDOZO L. REv. 1657, 1678 (2003).

349. Sara A. Rodriguez, The Impotence of Being Earnest, 33 NEw ENG. J. ON CRIM. \& CIV. CONFINEMENT 61, 98 n. 237 (2007); Diane Marie Amann, Guantanamo, 42 ColuM. J. TRANSNAT'L L. 263, 327 (2004).

350. S.P. Zochowski, Will Labour Keep its Promise?, 5 J. INT'L L. \& PRAC. 403, 411 (1996).

351. Campbell, supra note 341 , at 336.

352. Donohue, supra note 345, at 258.

353. Keith, supra note 268, at 427.

354. Northern Ireland (Emergency Provisions) Act, 1973, c. 53, § 21 (Eng.).

355. Schulhofer, supra note 343, at 1937.

356. Keith, supra note 268, at 427.

357. Campbell, supra note 341 , at 327 .

358. Id. at 327 n. 31. 
secret witnesses, and the use of "supergrasses," 359 a term used for "former paramilitary informants given inducements to testify against alleged coconspirators." ${ }^{360}$ These informants often testified against a large number of defendants in any one trial, giving some the impression that these prosecutions were show trials. $^{361}$

Between 1971 and 1974, while there were several bombings in England, at locations such as the Old Bailey, Whitehall, Scotland Yard and the Tower of London, ${ }^{362}$ special anti-terrorism legislation was not introduced outside of Northern Ireland. This changed in the wake of the politically inflammatory Birmingham pub bombings, in which 21 people were killed and roughly 168 injured. ${ }^{363}$ In response to popular outrage similar to that of $1939,{ }^{364}$ Parliament passed a new piece of anti-terrorism legislation after a single day of deliberation ${ }^{365}$ known as the Prevention of Terrorism (Temporary Provisions) Act 1974 (PTA 74), ${ }^{366}$ the provisions of which had been drafted a year earlier without being presented for passage. ${ }^{367}$ It was basically a reintroduction of PVA 39 with the addition of proscription, ${ }^{368}$ which allowed the government to proscribe any organization appearing to be "concerned in terrorism occurring in the United Kingdom and connected with Northern Irish affairs, or in promoting it or encouraging it."369 Membership in such a group warranted a punishment of up to 5 years in prison. ${ }^{370}$ It also became a crime to publicly display support of a proscribed organization, or to arrange a meeting of three or more persons that would be addressed by a member of a proscribed organization. ${ }^{371}$ Judicial review over the PTA 74 was technically greater than judicial review in the war powers cases and the earlier antiterrorism legislation because the courts began to refuse to allow "subjective language in statutes to negate their powers to review ministerial action," though in practice the court would "only be willing to interfere with a decision on this issue where the suspect could establish that the Secretary of State acted in bad faith, a burden impossible to discharge in practice." 372

Though the PTA 74, like PVA 39, was meant to be implemented for a limited period, it included the same obstacles to repeal as its predecessor.

359. John D. Jackson and Sean Doran, Conventional Trials in Unconventional Times: The Diplock Court Experience, 4 CRIM. L.F. 503, 507 (1993).

360. O'Connor, supra note 348, at 1697 n. 184.

361. Jackson, supra note 359 , at 507.

362. CoOGAN, supra note 330, at 293.

363. Id; see also BONNER, supra note 13 , at 39 .

364. Keith, supra note 268 , at 428 .

365. BONNER, supra note 13 , at 39.

366. Prevention of Terrorism (Temporary Provisions) Act, 1974, c. 56 (Eng.).

367. BONNER, supra note 13 , at 39.

368. DoNOHUE, supra note 12 , at 307.

369. BONNER, supra note 13, at 183.

370. BUNYAN, supra note 273, at 54-55.

371. BONNER, supra note 13 , at $183-84$.

372. Id. at 193. 
Structurally, it contained the same protection: it would expire after two years if not renewed by Parliament, ${ }^{373}$ but again, this nominally temporary legislation was renewed consistently, decades into the future. ${ }^{374}$ The barrier was largely political; the goals of the legislation were fuzzy, giving no real indication of what would have to be achieved before the emergency powers would cease to be necessary. ${ }^{375}$ In effect, "the burden shifted from those supporting emergency measures to prove that they were imperative, to individuals seeking to repeal the legislation needing to demonstrate that an emergency no longer existed." Ultimately, the powers of the PTA 74 were replaced by new legislation, the Terrorism Act 2000 (TA 2000), ${ }^{377}$ which was, in part, a blending of the PTA 74 and the EPA $73 .{ }^{378}$ Unlike the earlier measures, TA 2000 was explicitly intended to be permanent, and did not need to be renewed by Parliament. ${ }^{39}$ The other major difference from past anti-terrorism legislation was the use of a broader definition of terrorism, which expanded the focus from domestic terrorism to include international terrorism. ${ }^{380}$ Its applicability is no longer confined by geography, including any act "designed to influence the United Kingdom (or a foreign government) or to intimidate a population that is done for the purpose of advancing a political, religious, or ideological cause,",381 including those endangering life and public safety ${ }^{382}$ or disrupting power supplies, water supplies, or key computer systems. ${ }^{383}$

TA 2000 was in effect for a very short time before the events of September $11^{\text {th }}$ in the United States helped usher new legislation through Parliament, ${ }^{384}$ though it was passed without a sense of public emergency comparable to that which accompanied the United States Patriot Act. ${ }^{385}$ This new legislation was the Anti-Terrorism, Crime and Security Act 2001 (ATCSA). ${ }^{386}$ While its implementation brought some changes to the government's handling of terrorist finances, aviation security, and the nuclear industry, ${ }^{387}$ the most notable addition to Great Britain's antiterrorism regime was the possibility of indefinite detention "to prevent [a] suspected noncitizen

373. DONOHUE, supra note 12, at 307.

374. See Keith, supra note 268 , at $429-31$.

375. DoNOHUE, supra note 12, at 317.

376. Keith, supra note 268, at 429.

377. Terrorism Act, 2000, c. 11 (U.K.)

378. Keith, supra note 268, at 429.

379. Id. at 431 .

380. Richard Raimond, The Role of Indefinite Detention in Antiterrorism Legislation, 54

U. KAN. L. REV. 515, 533-34 (2006).

381. Young, supra note 339, at 74.

382. Id.

383. Keith, supra note 268 , at 432.

384. Id. at 432.

385. Id. at 433-34.

386. Anti-Terrorism, Crime and Security Act, 2001, c.24 (U.K.).

387. Sir David Williams, The United Kingdom's Response to International Terrorism, 13 IND. INT'L \& COMP. L. REv. 683, 693 (2003). 
terrorist from engaging in any future terrorist activities." 388 This measure could only be utilized against noncitizens who could not be deported because the United Kingdom's human rights treaty obligations prevented it from deporting a person to a destination country where the person faced the possibility of being tortured. $^{389}$

This was a significant departure from past practice in the UK - while internment for reasons related to terrorism had been instituted repeatedly in Northern Ireland, ${ }^{390}$ it had never been used to combat terrorism in the mainland. ${ }^{391}$

The possibility of indefinite detentions conflicted with the United Kingdom's obligations under the European Convention on Human Rights (ECHR), an agreement protecting civil and political rights similar to the protections found in the U.S. Bill of Rights. ${ }^{392}$ Article 15 of the ECHR permits its members to derogate from some of its requirements "[i]n time of war or other public emergency threatening the life of the nation," which is essentially a means of condoning the use of emergency powers, but only to the extent "strictly required by the exigencies of the situation."393 At the same time, the Human Rights Act $1998^{394}$ allows the House of Lords, in its judicial capacity, to "declare a statute is incompatible with fundamental human rights norms,"395 with the expectation that Parliament would then modify such a statute to remove the incompatibility. ${ }^{396}$

When a case involving detention under ATCSA came before the House of Lords in accordance with the Human Rights Act $1998,{ }^{397}$ the Law Lords evaluated two questions: (1) whether a "public emergency threatening the life of the nation within the meaning of Article 15(1)" existed and (2) whether the

388. Keith, supra note 268 , at 434.

389. Raimond, supra note 380 , at 534 .

390. Donohue, supra note 345, at 318 ("In Northern Ireland, for instance, between 1922 and 1972, internment occurred on four occasions"); see also Christopher K. Connolly, Living on the Past: the Role of Truth Commissions in Post-Conflict Societies and the Case Study of Northern Ireland, 39 CORNELL INT'L L.J. 401, 415 (2006), noting

[t]he rule of law never applied to Northern Ireland in the same way as it did to other parts of the UK. Britain turned a blind eye towards the discriminatory practices of Northern Ireland's Unionist government between 1921 and 1969, and after the outbreak of the Troubles it implemented practices of prolonged internment and secret, non-jury "Diplock Courts" that were employed liberally, Id. especially against the Catholic community.

391. Keith, supra note 268 , at 434.

392. Id. at 451 .

393. Raimond, supra note 380 , at 535 .

394. Human Rights Act, 1998, c. 42 (U.K.).

395. Mark Tushnet, Weak-Form Judicial Review and "Core" Civil Liberties, 41 HARv.

C.R.-C.L. L. REV. 1, 7 (2006).

396. Id.

397. A v. Sec'y of State of Home Dep't, [2005] All E.R. 169 (Eng.) 
derogation was "strictly required by the exigencies of the situation." 398 The Law Lords were deferential in evaluating the first element, indicating it was a political judgment for which the political branches were better suited, ${ }^{399}$ but found detention under ATCSA violated the proportionality requirement of the second element, because it ignored similar threats presented by British citizens (noting evidence that roughly a thousand had attended training camps in Afghanistan), and allowed for the detention of individuals who had links to a terrorist organization presenting no direct threat to the United Kingdom, divorcing detention from the original emergency justifying derogation..$^{400}$

The House of Lords "strongly recommend[ed]" the detention aspect of the ATCSA be replaced, suggesting new legislation should either deal with all terrorism, "whatever its origin or the nationality of its suspected perpetrators" or be drafted in a manner requiring no derogation from the ECHR. ${ }^{401}$ Following the decision, Parliament abolished the detention provisions created under the ATCSA, replacing detention with the power to issue "control orders" created by the Prevention of Terrorism Act 2005 (PTA 2005). ${ }^{402}$ These control orders, issued against terrorism suspects, can require a range of measures, including curfews, electronic tagging, forbidding communication with other terror suspects, and indefinite house arrest; a control order would apply equally to citizens and noncitizens. It is unclear whether some of these provisions also conflict with the ECHR Article $5 .^{403}$

Mostly recently, in response to the London bombings in July $2005,{ }^{404}$ the United Kingdom enacted the Terrorism Act 2006 (TA 2006) ${ }^{405}$ after six months of debate. ${ }^{406}$ PTA 74 had already criminalized speaking in support of proscribed organizations, and TA 2000 expanded the subject matter basis for proscribing a group. TA 2006 expanded the criminalization of speech, ${ }^{407}$ making it a crime to make "a statement that is likely to be understood by some or all of the members of the public to whom it is published as a direct or indirect encouragement or other inducement to them to the commission, preparation or instigation of acts of terrorism," by "glory[ing] the commission or preparation (whether in the past, in the future or generally) of such acts." ${ }^{\prime 408}$

398. Raimond, supra note 380 , at 537.

399. Mark Elliott, United Kingdom: Detention Without Trial and the "War on Terror," 4 INT'L J. CONST. L. 553, 555-56 (2006).

400. Raimond, supra note 380 , at 538 .

401. Id. at 539.

402. Prevention of Terrorism Act, 2005, c. 2 (U.K.).

403. Raimond, supra note 380, at 539; Jane Andrewartha, English Maritime Law Update: 2005, 37 J. MAR. L. \& CoM. 359 (2006).

404. Kent Roach, Must We Trade Rights for Security? The Choice Between Smart, Harsh, or Proportionate Security Strategies in Canada and Britain, 27 CARDOZO L. REV. 2151, 2172 (2006).

405. Terrorism Act, 2006, c. 11 (U.K.).

406. Barnum, supra note 111 , at 292 n. 134.

407. Roach, supra note 404, at 2179-80.

408. Terrorism Act, 2006, c. 11 (U.K.). 


\section{FINAL THOUGHTS}

The House of Lords' effect on the indefinite detention portion of the Anti-Terrorism, Crime and Security Act 2001 has led to some controversy in the United Kingdom, because, even though the House of Lords was acting under the authorization of another piece of Parliamentary legislation, it represented a boldness that has been absent from the British judiciary for quite some time. ${ }^{409}$ Commentators wondered to what degree the Human Rights Act 1998 would free the British courts from their traditional shackles, and if through the interpretation of the European Convention on Human Rights the courts would help to curb "the worst excesses of majoritarianism." 410

Either way, British courts would lack the power to strike down laws violating the ECHR, but would that make a significant difference? No conclusive reason exists to believe the power of judicial review itself has prevented majoritarian excess. This Note has documented instances in which the U.S. Supreme Court bent over backward to facilitate the panicked, majoritarian impulses of the country. Judge Learned Hand once said:

I often wonder whether we do not rest our hopes too much upon constitutions, upon laws and upon courts. These are false hopes. . . . Liberty lies in the hearts of men and women; when it dies there, no constitution, no law, nor court can save it; no constitution, no law, no court can even do much to help it. While it lies there it needs no constitution, no law, no court to save it. ${ }^{411}$

It may be that the benefit provided to the United Kingdom by the ECHR and the HRA - an explicitly enumerated system of rights, and an independent body of judges to gauge how well contemporary legislation conforms to those rights - is the primary benefit that America has received from the Bill of Rights and judicial review. As Madison said when he argued in favor of adopting the Bill of Rights:

It may be thought that all paper barriers against the power of the community are too weak to be worthy of attention. I am sensible they are not so strong as to satisfy gentlemen of every description who have seen and examined thoroughly the texture of such a defense; yet, as they have a tendency to impress some degree of respect for them, to establish the public opinion in their favor, and rouse the attention of the whole community, it may be one means to control the majority

409. See Elliott, supra note 399, at 553.

410. Id. at 560-61.

411. Cole, supra note 61, at 2568. 
from those acts to which they might be otherwise inclined. ${ }^{412}$

Even if the only real check against a tyrannical majority is political sentiment, our straits may not be overly dire. Support for human rights in the United Kingdom was great enough to force Parliament to alter course, and the United States has witnessed a dramatic increase in the number of groups devoted to human and civil rights in recent years, especially since the end of the Cold War. ${ }^{413}$ Then again, polls in the United States have found that almost half of the population associate Islam with violence, a quarter holds extreme antiMuslim views, ${ }^{414}$ nearly one-quarter believes that the government should be allowed to use torture in some circumstances, ${ }^{415}$ while popular television pundits call for explicit racial profiling. ${ }^{416}$ The use of racial profiling by London police, along with a shoot-to-kill policy for potential terrorists, has also been condoned in some quarters. ${ }^{417}$

How the chips will fall in our time is anyone's guess. As for myself, I will leave you with the words of Mark Twain: history does not repeat itself - it rhymes. $^{418}$

412. CURTIS, supra note 255, at 21.

413. Id. at 2584-85.

414. Jim Lobe, Sharp Rise in Anti-Muslim incidents reported, NEW PITTSBURGH COURIER, Sept 28, 2006, at A8, available at http://www.washingtoninformer.com/RELAntiMuslim2006Sep28.html.

415. See Marks, supra note 36, at 572.

416. Bill O'Reilly, Talking Points: More Airline Terror Chaos, Fox News, http://www.foxnews.com/story/0,2933,208900,00.html (August 17, 2006).

Now it's long past time for the USA to stop the nonsense and institute profiling at airports. We're not at war with Granny Frickett. We're at war with Muslim fanatics. So all young Muslims should be subjected to more scrutiny than Granny. And we should blend some Israeli screening procedures with our own. For example, trained security people should receive the passenger list on every flight and interview those people most likely to be terrorists... . Passengers who are Muslims ages 16 to 45 all should be spoken with. And if the ACLU doesn't like it, tough. This isn't racial profiling. This is criminal profiling. . . The wrong-headed notion that you can't scrutinize Muslims, even though the terror war is driven by them, is beyond dumb. It's self-defeating and acutely dangerous. Profiling must begin now.

Id. See also Ann Coulter, Terrorists Win: Deodorant Banned from Airlines, http://www.anncoulter.com/cgi-local/article.cgi?article=143 (August 16, 2006) ("Without the ethnic profiling going on outside of airports, no security procedure currently permissible inside airports would have prevented a terrorist attack that would have left thousands dead .... We have to target the fanatics themselves. Baby formula doesn't kill people. Islamic fascists kill people").

417. Glenn Frankel \& Tamara Jones, In Britain, a Divide Over Racial Profiling, WASHINGTON POST, July 27, 2005, at A01, available at http://www.washingtonpost.com/wpdyn/content/article/2005/07/26/AR2005072601789.html; 'Shoot-to-kill' policy to remain, BBC NEwS, July 25, 2005, http://news.bbc.co.uk/1/hi/uk/4713199.stm.

418. Lawrence P. Wilkins, Symposium: Then, Now and Into the Future: A Century of Legal Conflict and Development, 28 IND. L. REv. 135, 137 (1995). Apparently some dispute exits as to whether Mr. Twain actually uttered these words. Id. at n. 4. However, I am inclined 
